\title{
Odisseias do conceito moderno de história: Necrológio de Francisco Adolfo de Varnhagen, de Capistrano de Abreu, e $O$ pensamento histórico no Brasil nos últimos cinquenta anos, de Sérgio Buarque de Holanda, revisitados
}

\author{
Mateus Henrique de Faria Pereira ${ }^{1}$ \\ Pedro Afonso Cristovão dos Santos ${ }^{2}$
}

\section{Resumo}

Neste artigo, procuramos refletir sobre as tensões do conceito moderno de história a partir de dois textos importantes enquanto avaliações da historiografia brasileira e considerações sobre a escrita da história do Brasil, a saber: Necrológio de Francisco Adolfo de Varnhagen (1878), de João Capistrano de Abreu, e $O$ pensamento histórico no Brasil nos últimos cinquenta anos (1951), de Sérgio Buarque de Holanda. Pensandoos na chave do dito conceito moderno de história, isto é, como representativos de uma nova experiência do tempo, marcada pela diferença em relação ao passado, e por um novo horizonte de expectativas em relação ao futuro, que remodela a escrita da história, vemos nesses textos, marcados por tensões por vezes dicotômicas, entre estudos particulares e obras de síntese, teoria e empiria, objetividade e subjetividade, inquietações ainda relevantes para os historiadores.

\section{Palavras-chave}

Capistrano de Abreu, Sérgio Buarque de Holanda, conceito moderno de história, historiografia brasileira.

Recebido em 15 de abril de 2009

Aprovado em 27 de outubro de 2009

$1 \quad$ Professor da Universidade Federal de Ouro Preto. E-mail: matteuspereira@gmail.com

2 Mestre em História pelo Programa de História Social da Faculdade de Filosofia, Letras e Ciências Humanas da Universidade de São Paulo. Bolsista CNPq durante a elaboração deste artigo. E-mail: pedro.afonso.santos@usp.br 


\section{Journeys of the modern conception of history: Capistrano de Abreu's Necrológio de Francisco Adolfo de Varnhagen and Sérgio Buarque de Holanda's O pensamento histórico no Brasil nos últimos cinquenta anos revisited}

Mateus Henrique de Faria Pereira

Pedro Afonso Cristovão dos Santos

Abstract:

This article seeks to reflect on the tensions internal to the modern conception of history through two important texts concerning Brazilian historiography and the writing of Brazilian history: Capistrano de Abreu's Necrológio de Francisco Adolfo de Varnhagen (1878) and Sérgio Buarque de Holanda's $O$ pensamento histórico no Brasil nos últimos cinquenta anos (1951). Considering both in the light of the modern conception of history, as representatives of a new experience of time, characterized by the difference towards the past, and by a new horizon of expectations about the future, which changes the way history is written, we see them both marked by tensions such as particular studies and synthesis, theory and empirical work, objectivity and subjectivity, still relevant to historians.

Keywords

Capistrano de Abreu, Sérgio Buarque de Holanda, modern conception of history, Brazilian historiography. 


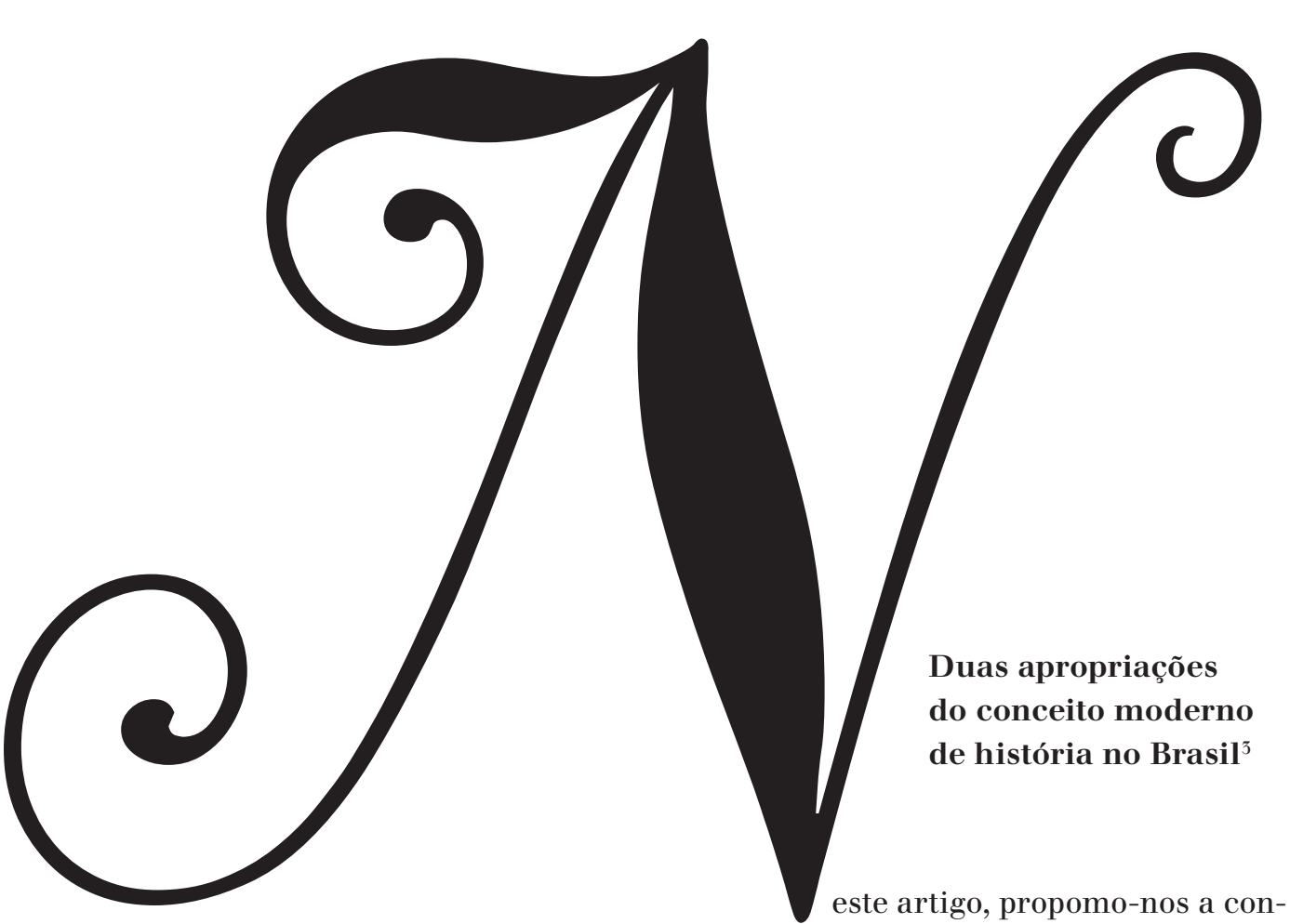

frontar dois textos fundamentais da história da historiografia brasileira, a saber: Necrológio de Francisco Adolfo de Varnhagen, Visconde de Porto Seguro, escrito por Capistrano de Abreu e publicado quando da morte do autor da História geral do Brasil, em 1878, e O pensamento histórico no Brasil nos últimos cinquenta anos, de autoria de Sérgio Buarque de Holanda, publicado em $1951^{4}$. Ambos saíram originalmente na imprensa diária do Rio de Janeiro (o Necrológio, no Jornal do Commercio; O pensamento histórico em o Correio da Manhã) e têm como característica comum o fato de proporcionarem aos leitores panoramas da produção historiográfica brasileira dos períodos de que tratam (mesmo no artigo de Capistrano, centrado em uma figura individual, encontramos uma avaliação mais abrangente da historiografia brasileira até Varnhagen, assim como da historiografia contemporânea a esse autor). Embora a obra e o pensamento de Capistrano de Abreu tenham sido importantes para a produção de Sérgio Buarque de Holanda, em muitos aspectos e momentos, uma aproximação desses dois textos, separados no tempo por mais de setenta anos, não é de

3 Agradecemos a Fernando Nicolazzi, Henrique Estrada Rodrigues, Juliana Melo, Pedro Caldas, Paulo Teixeira Iumatti, Valdei Lopes de Araújo, além dos dois pareceristas da Revista do Instituto de Estudos Brasileiros, pelas leituras atenciosas e sugestões. Apoio: Fundação de Amparo à Pesquisa do Estado de Minas Gerais (Fapemig) e Conselho Nacional de Desenvolvimento Científico e Tecnológico (CNPq).

4 Os dois textos encontram-se transcritos ao final deste artigo. 
forma alguma óbvia. Os momentos particulares da história do Brasil em que esses textos foram escritos e publicados (os anos já de crise do Império, no caso de Capistrano, e a democracia pós-Estado Novo, quando Sérgio Buarque escreveu) e as diferentes condições para os estudos históricos no Brasil nesses momentos, com o surgimento das universidades, não podem ser ignorados. Ambos os textos apresentam, mais do que avaliações específicas, considerações gerais sobre o fazer história e as características que deve possuir um historiador, as quais cremos poderem ser pensadas a partir de certas mudanças na forma de se vivenciar o tempo e conceber a história. Desse modo, Capistrano de Abreu, em 1878, e Sérgio Buarque de Holanda, em 1951, levantam questões que permanecem relevantes para a história da historiografia, tais como: a relação entre monografia e obra de síntese, teoria e empiria, objetividade e subjetividade, entre outras. Nossa reflexão procura relacionar os textos em um escopo conceitual definido principalmente a partir dos estudos de François Hartog e Reinhart Koselleck, discutindo o regime de historicidade e a experiência do tempo moderna, que se constituíram a partir do fim do século XVIII. Capistrano e Sérgio estariam inseridos, assim, nessa espécie de "longa duração".

Nessa direção, é preciso realçar que, da experiência do passado, das histórias e crônicas que ensinavam as lições da história, emerge, após a Revolução Francesa, um conceito de história como realidade unificada e processual. Ela passa, então, a ser entendida como singular coletivo ; " "além das histórias há História”, escreve, no século XIX, Gustav Droysen ${ }^{6}$. Nessa nova forma de se relacionar com o tempo, as luzes vêm do futuro e o passado deve ser avaliado, posto em dúvida. Surge daí uma consciência crítica em relação ao espaço de experiência, traduzido por um sentimento de distância e diferença em relação ao passado. Num primeiro momento de dissociação entre história e moral, em que a história como relato de acontecimentos únicos impõe-se à história enquanto coletânea de exemplos, o historiador foi visto como reprodutor da verdade nua, como um pintor, pois era possível imitar os fatos por meio da representação ${ }^{7}$. Essa teoria do conhecimento histórico começou a ser sofisticada a partir da segunda metade do século XIX. Desse

5 ARENDT, Hanna. Entre o passado e o futuro. São Paulo: Perspectiva, 1992; HARTOG, François. Régimes d'historicité : présentisme et expériences du temps. Paris: Seuil, 2003; KOSELLECK, Reinhart. Futuro passado: contribuição à semântica dos tempos históricos. Rio de Janeiro: Contraponto; PUC-Rio, 2006.

6 Essa perspectiva de Droysen é retomada por ARENDT, Hanna. op. cit.; HARTOG, François. Régimes d'historicité: présentisme et expériences du temps. op. cit. e KOSELLECK, Reinhart. op. cit. Sobre Droysen, ver: CALDAS, Pedro S. P. A atualidade de Johann Gustav Droysen: uma pequena história de seu esquecimento e de suas interpretações. Lócus, Juiz de Fora: UFJF, v. 12, p. 95-111, 2006. 
processo, extraímos uma das hipóteses de nosso texto, qual seja: a de que o conceito moderno de história é marcado por tensões, muitas vezes apresentadas de forma dicotômica, entre concepções cientificistas e complexas; dedutivas e indutivas; objetivistas e subjetivistas; generalistas e particularistas; continuistas e descontinuistas.

Em boa medida, e esta é nossa outra hipótese, os textos, publicados em jornais ${ }^{8}$, Necrológio de Francisco Adolfo de Varnhagen, escrito em 1878 por Capistrano de Abreu, e O pensamento histórico no Brasil nos últimos cinquenta anos, por Sérgio Buarque de Holanda, em 1951, são vistos aqui como exemplos paradigmáticos da consciência complexa da dimensão da

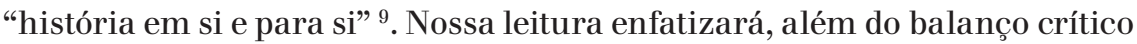
contido nesses textos, o quanto eles revelam da concepção de história de seus autores, marcada por tensões características do conceito moderno de história. Nesse sentido, nossa intenção é refletir, ao final, sobre como esses dois historiadores perceberam a questão do progresso do conhecimento histórico a partir da relação entre estudos particulares e obras de síntese. Pensamos, dessa forma, que uma potencialidade comum aos dois textos que serão analisados está em perceber os limites de certo tipo de concepção moderna realista da história e em irem em direção a uma percepção mais complexa e mais rica, fruto da pesquisa e da (re)escrita da história. Vale ressaltar que José Honório Rodrigues considerou os dois textos em questão, ao lado de Os historiadores do Brasil no século XIX, de Alcides Bezerra, como precursores da história da História do Brasil, por serem, em sua visão, as primeiras análises críticas de nossa produção historiográfica ${ }^{10}$.

Valendo-nos das contribuições da história cruzada, pretendemos operar algumas articulações entre esses dois textos, procurando nos apropriar, de forma criativa, da referida metodologia ${ }^{11}$. Apoiamo-nos

8 Sobre a importância de textos escritos em jornais para a história da historiografia, ver, entre outros, GOMES, Ângela de Castro. História e historiadores. Rio de Janeiro: FGV, 1996.

9 Para uma análise que procura articular a expressão "história em si e para si” com o conceito moderno de história, ver KOSELLECK, Reinhart. op. cit., p. 81. A expressão surge, segundo o autor, no último terço do século XVIII.

10 RODRIGUES, José Honório. História da história do Brasil. Primeira parte: historiografia colonial. São Paulo: Companhia Editora Nacional, 2. ed., 1979. p. XV-XVI. Em nota, o autor acrescentou ainda MELLO, Astrogildo Rodrigues de. Os Estudos Históricos no Brasil. Revista de História, n. 6, $195^{1}$ (mesmo ano do artigo de Sérgio Buarque de Holanda). Uma importante relação entre os dois textos aqui analisados foi elaborada por GUIMARÃES, Lúcia M. P. Sérgio Buarque de Holanda na trilha de Capistrano de Abreu: caminhos do historismo alemão. Cadernos do Núcleo de Pesquisa e Estudos Históricos. Rio de Janeiro: UFRJ, v. 1, n. 1, p. 79-94, 1996.

11 Sobre a história cruzada, ver, entre outros, WERNER, Michael; ZIMMERMANN, Bénédicte. Penser l'histoire croisée: entre empirie et réflexivité. Annales. 
também nas sugestões de Manoel Luiz Salgado Guimarães, para quem a historiografia deve ter como objetivo a "interrogação sistemática das memórias construídas". Nesse sentido, a historiografia pode ser definida "como investigação sistemática acerca das condições de emergência dos diferentes discursos sobre o passado"12.

O período entre 1878 e 1951 é visto aqui como um entre-lugar, ou seja, entre duas institucionalizações da escrita da história, entre a história pensada e produzida pelo IHGB e pela Universidade, para tomarmos aquelas que parecem ser as instituições mais marcantes de cada momento ${ }^{13}$. Os dois textos sobre os quais nos debruçamos aqui são como eventos que abrem e fecham caminhos. Textos elaborados por "homens-pontes", "elos"; passagens de gerações, marcos, símbolos e "monumentos" da historiografia brasileira. Capistrano de Abreu pode ser visto como um "elo" entre duas formas de fazer história, a oitocentista (ou, mais precisamente, a história de meados do Oitocentos), e a "modernista", por assim dizer, já das primeiras décadas do século XX. Em análise já clássica Alice P. Canabrava afirma que "a História como narrativa do empírico, dentro do juízo moral, [...] tem [em] Varnhagen, no Brasil, seu representante máximo", ao passo que "a história no quadro das ciências sociais, numa dimensão nova" tem na figura de Capistrano "a significação de um elo entre essas duas gerações", sendo que Capistrano deve ser entendido ainda no contexto de sua época, a mesma de intelectuais como Silvio Romero, Tobias Barreto e Euclides da Cunha. Essa geração expressou por meio de produções individuais a "inquietude em compreender a realidade brasileira com o apelo das novas correntes científicas que, ao seu tempo, se desenvolviam vigorosamente no campo das ciências do Homem"14.

Paris: EHESS, v. 58, n. 1, p. 7-36, 2003 e De la comparaison à l'histoire croisée. $L e$ Genre Humain, Seuil, n. 42, 2004 .

GUIMARÃES, Manoel L. S. Memória, história e historiografia. In: BITTENCOURT, José Neves; BENCHETRIT, Sara Fassa; TOSTES, Vera Lúcia Bottrel. (Orgs.). História representada: o dilema dos museus. Rio de Janeiro: Museu Histórico Nacional, 2003. p. 92. Nossa investigação está também bastante próxima do que Valdei de Araújo define como sendo história da historiografia. A esse respeito, ver ARAÚJO, Valdei Lopes. Sobre o lugar da história da historiografia como disciplina autônoma. Lócus, Juiz de Fora: UFJF, v. 12, p. 79-94, 2006.

13 Embora, em ambos os momentos, a produção historiográfica não tenha sido exclusividade dessas duas instituições. Para 1878 , talvez seja correto acrescentar a Biblioteca Nacional e o Colégio Pedro II, se considerarmos a biografia de Capistrano, e os institutos históricos regionais. Em 1951, também o Museu Paulista, o Museu Histórico Nacional do Rio de Janeiro, e ainda o IHGB, os institutos regionais e a Biblioteca Nacional, são componentes do campo de instituições existentes.

14. CANABRAVA, Alice. Apontamentos sobre Varnhagen e Capistrano. Revista de História, São Paulo: USP, n. 18 (88), out./dez. de 1971. p. 424. 
Capistrano de Abreu, quando escreveu e publicou o texto que será analisado, começava a afirmar-se no campo dos estudos históricos. Um ano depois de publicado o Necrológio, Capistrano passaria em concurso para o corpo de funcionários da Biblioteca Nacional do Rio de Janeiro, onde entraria em contato com estudiosos como Ramiz Galvão e Alfredo do Vale Cabral. Provavelmente frequentador da Biblioteca desde sua chegada ao Rio de Janeiro, em 1875, vindo do Ceará, Capistrano ampliaria seus conhecimentos de paleografia e de história por meio do contato com os documentos daquele acervo. Sua entrada para a Biblioteca Nacional foi comumente vista por seus biógrafos como a afirmação de sua "vocação" para a história, como um ponto decisivo em sua trajetória na direção dos estudos históricos ${ }^{15}$. No entanto, já em 1877 encontravam-se, na imprensa, textos de Capistrano de Abreu sobre história e mesmo sobre historiografia ${ }^{16}$. A partir de 1879, cada vez mais publicará pesquisas originais suas ${ }^{17}$. Quando, em 1882, tornou-se vaga a cadeira de História do Brasil no Imperial Colégio Pedro II, a mais prestigiosa instituição de ensino daquele tempo, Capistrano candidatou-se, e foi aprovado em concurso, com aquele que foi seu primeiro grande trabalho em história: uma tese sobre o descobrimento do Brasil, escrita e publicada em 1883, considerada muito superior aos trabalhos concorrentes, e mesmo muito à frente da produção contemporânea em estudos históricos. A tese, fundamentada em fontes primárias e discutindo de forma crítica as próprias fontes e as hipóteses levantadas por outros historiadores, rejeita uma apresentação dos fatos históricos como dados, encarando o passado como um espaço diverso do presente e desconhecido, sondável apenas mediante investigação sistemática, e, mesmo assim, suscetível a um conhecimento imperfeito ${ }^{18}$.

15 Ver, por exemplo, as biografias de VIANA, Hélio. Capistrano de Abreu: ensaio bibliográfico. Rio de Janeiro: MEC, 1955, e a de MENEZES, Raimundo de. Capistrano de Abreu: um homem que estudou. São Paulo: Melhoramentos, 1956. É Viana quem afirma que a entrada para a Biblioteca Nacional "iria decidir, definitivamente, sua [de Capistrano] vocação de historiador” (p. 14).

16 Como uma resenha crítica da obra História da fundação do Império brasileiro, de João Manuel Pereira da Silva, publicada em $O$ Globo, de 10 de março de 1877, e reproduzida em ABREU, João Capistrano de. Ensaios e estudos: crítica e história. Rio de Janeiro: Civilização Brasileira; Brasília: INL, quarta série, 1976. p. 37-41.

17 Como a série de artigos denominada Gravetos de história pátria, publicada na $G a$ zeta de Notícias entre 1881 e 1882 e também reproduzida em ABREU, João Capistrano de. Ensaios e estudos: crítica e história. op. cit., p. 291-z16.

18 Relatos do concurso e comparações entre o trabalho apresentado por Capistrano e o de seus concorrentes podem ser encontrados nos biógrafos citados (o alemão Carl Von Koseritz, em viagem pela Corte naquele momento, presenciou o concurso e produziu um depoimento comumente usado pelos biógrafos de Capistrano). A tese em si foi objeto de estudo de ARAÚJO, Ricardo Benzaquen de. Ronda Noturna: 
Comungamos da ideia de que Sérgio Buarque de Holanda, por sua vez, também pode ser interpretado como um elo: "poder-se-ia dizer que Sérgio Buarque foi um homem-ponte entre os intelectuais da 'rua' e os das “instituições" "19, pontes entre o modernismo, o ensaísmo e a história acadêmica. Entre 1946 e 1956, Sérgio Buarque de Holanda dedicou-se à direção do Museu Paulista e ingressou na Escola de Sociologia e Política de São Paulo. Foi nesse ínterim, que o autor escreveu uma série de textos em defesa da institucionalização universitária e da profissionalização acadêmica. Não por acaso seus três principais livros tidos como "históricos" foram publicados nas décadas de 1940 e 1950. São eles: Monções (1945), Caminhos e fronteiras (1957) e Visões do paraíso $(1957)^{20}$. Esse movimento é denominado por Robert Wegner de "do ensaísmo à historiografia". Para Wegner, "se antes a atividade intelectual era vista como 'missão', agora [trata-se do comentário de um texto buarquiano de 1948] Sérgio Buarque enxerga a possibilidade de que tal atividade seja concebida como "profissão" "21. Wegner ainda afirma: "Sérgio Buarque saúda a institucionalização das ciências humanas, advogando por sua novidade no contexto cultural brasileiro e defendendo a importância do intelectual moldado pela atividade miúda da inquirição"22. Nessa direção, o texto $O$ pensamento histórico no Brasil nos últimos cinquenta anos (1951) é lido por nós como uma defesa da especialização, que é ao mesmo tempo uma defesa da institucionalização. O referido artigo não deixa de ser uma forma de intervenção em um projeto aberto, em disputa, inconcluso e em construção. Para Sérgio Buarque, como veremos, a história só teria a ganhar com tal processo.

narrativa, crítica e verdade em Capistrano de Abreu. Estudos Históricos, Rio de Janeiro, n. 1, 1988, p. 28-54, justamente à luz do conceito moderno de história e da moderna experiência do tempo.

19 WEGNER, Robert. Latas de leite em pó e garrafas de uísque: um modernista na universidade. In: EUGÊNIO, João Kennedy; MONTEIRO, Pedro Meira. Sérgio Buarque de Holanda: perspectivas. Campinas: Editora da Unicamp/Rio de Janeiro: EdUERJ, 2008. p. 483.

20 Ver, entre outros, DIAS, Maria Odila da Silva. Sérgio Buarque de Holanda na USP. Estudos Avançados, v. 8, n. 22, 1994; WEGNER, Robert. A conquista do oeste: a fronteira na obra de Sérgio Buarque de Holanda. Belo Horizonte: Editora da UFMG, $2000 ; \ldots$. Da generalidade à poeira dos arquivos: Sérgio Buarque de Holanda nos anos 1940. Revista contemporaneidade e educação, Rio de Janeiro, ano VII, n. 11, 2002; GUIMARÃES, Eduardo Lima. A modernidade brasileira reconta as tradições paulistas. In: EUGENIO, João Kennedy; MONTEIRO, Pedro Meira. Sérgio Buarque de Holanda: perspectivas. op. cit., p. 37-62.

21 WEGNER, Robert. Latas de leite em pó e garrafas de uísque: um modernista na universidade. op. cit., p. 491 .

22 Idem, ibidem. 


\section{O Necrológio de Francisco Adolfo de Varnhagen e aspectos da complexidade do conceito moderno de história}

No final do século XIX, conviviam no Brasil, segundo Francisco Iglésias, três formas de se representar o passado: "1) autores e obras na antiga orientação de crônica; 2) cultivo do eruditismo, cujo nome principal foi Varnhagen; 3) autores e obras com nível moderno, de pesquisa intensa, metodologia segura, temática original, elaboração superior" ${ }^{23}$. Nesse último grupo, do qual Capistrano de Abreu fazia parte, encontramos também Silvio Romero, Euclides da Cunha, Oliveira Lima, Tobias Barreto, Eduardo Prado, Manoel Bomfim, João Ribeiro, entre outros. Tais autores foram marcados pelas transformações dos anos 1870, o período do Gabinete Rio Branco, da Lei do Ventre Livre, do fim da Guerra do Paraguai e do início do movimento republicano.

Essa época conturbada abriu espaço para o questionamento da relação de continuidade histórica entre Portugal e Brasil, e/ou a inversão do sentido de seu valor, no âmbito dos estudos históricos. Isto significa dizer que, no momento da crise do Império começou-se a se questionar se o Brasil era, como país, um desdobramento de Portugal, sua antiga metrópole (uma das premissas da historiografia oitocentista, organizada em torno do Instituto Histórico e Geográfico Brasileiro), ou uma nação própria, fruto de desenvolvimento particular e autônomo ${ }^{24}$. Questionou-se também se essa continuidade, caso existisse, não seria justamente a raiz de nossos problemas sociais e políticos, ou seja, se não seria a herança portuguesa a causa dos males da sociedade brasileira. Índice dessa reavaliação é a grande popularidade, entre os autores da geração de 1870, no Brasil, da obra O Brasil e as colônias portuguesas (1880), do historiador português Oliveira Martins, conforme aponta Angela Alonso. Segundo a autora, nesse livro,

Oliveira Martins observa que a colonização do Brasil acontecera em meio à decadência da metrópole. As incursões de Portugal na África $\mathrm{e}$ no Brasil são descritas como uma triangulação, formando um sistema de exploração colonial: bem-sucedido por redundar em colonização, malogrado por estar na raiz do declínio do Império português. ${ }^{25}$

23 IGLÉSIAS, Francisco. Os historiadores do Brasil: capítulos de historiografia brasileira. Rio de Janeiro: Nova Fronteira; Belo Horizonte: UFMG, IPEA, 2000. p. 94-95.

24 Sobre essa historiografia na primeira metade do oitocentos, o posicionamento em relação a Portugal e à experiência moderna do tempo, ver ARAÚJO, Valdei Lopes. $A$ experiência do tempo: conceitos e narrativas na formação nacional brasileira (18131845). São Paulo: Aderaldo \& Rothschild (Hucitec), 2008.

25 ALONSO, Angela. Idéias em movimento: a geração 1870 na crise do Brasil-Império. São Paulo: Paz e Terra, 2002. p. 193. 
Essa obra teria sido fundamental para Joaquim Nabuco, por exemplo, na elaboração de $O$ abolicionismo; pois o teria ajudado a ver que "os problemas brasileiros seriam estruturais, resultados da colonização"26.

Destarte, se compararmos algumas das ideias em voga na historiografia no momento em que Capistrano de Abreu se pôs a estudar e a escrever estudos históricos, com as da geração de Varnhagen, observamos que, se Varnhagen escreveu quando a monarquia se consolidava, a "geração 1870" escreveu quando a monarquia e a escravidão estavam sendo seriamente questionadas. Esses autores começaram a se defrontar com as problemáticas relativas à construção da Nação em um novo momento, repensando o problema da identidade nacional ${ }^{27}$.

Tendo em vista os aspectos aqui levantados, como o próprio Capistrano avaliou a historiografia varnhageniana? Para Capistrano, em $\mathrm{ONe}$ crológio de Varnhagen, publicado inicialmente em duas partes no Jornal do Commercio, Varnhagen era o "grande exemplo a seguir e a venerar"28; podia se gabar "de que um só facto não existia que não tivesse pessoalmente examinado, ao passo que os factos materiaes por elle descobertos, ou rectificados, igualavam, si não execediam, aos que todos os seus predecessores tinham adduzido", como escreve na primeira parte, publicada no dia 16 de dezembro de $1878^{29}$. Quatro dias depois, em 20 de dezembro, saía a segunda parte do estudo, a mais famosa e crítica. Nela, Capistrano caracteriza Varnhagen como um trabalhador possante, explorador incansável, trazendo nas mãos pérolas e corais, isto é, documentos importantes extraídos dos arquivos europeus, sendo fundamental seu trabalho de exposição factual. Entretanto, "Varnhagen não primava pelo espírito compreensivo e sympathico, que, imbuindo o historiador dos sentimentos e situações que atravessa - o torna contemporaneo e confidente dos

26 Idem, ibidem, p. 194. Capistrano de Abreu escreveu uma resenha desse livro de Oliveira Martins para a Gazeta de Notícias, publicada em duas partes; uma, a 19, outra, a 22 de outubro de 1880 . Na resenha, apontou inexatidões factuais da obra, visando colaborar para uma segunda edição, pois, "apesar de todos os seus defeitos, o Brasil e as colónias portuguesas têm idéias novas e considerações de muito alcance, que apresentam a história do Brasil sob faces ainda não estudadas”. ABREU, Capistrano de. Ensaios e estudos: crítica e história. op. cit., p. 160.

27 Ver, entre outros, SCHWARCZ, Lilia Moritz. O espetáculo das raças. São Paulo: Companhia das Letras, 1989; DIEHL, Astor Antônio. A cultura historiográfica brasileira (do IHGB aos anos 1930). Passo Fundo: EDIUPF, 1998; CARVALHO, Jose Murilo de. Pontos e bordados. Belo Horizonte: UFMG, 2001 e REIS, José Carlos. Identidades do Brasil. Rio de Janeiro: FGV, 2000.

28 ABREU, Capistrano de. Necrológio de Francisco Adolfo de Varnhagen. Ensaios e estudos: crítica e história, Primeira série. Rio de Janeiro: Livraria Briguiet, 1931. p. 133.

29 Idem, ibidem, p. 130. 
homens e acontecimentos. A falta de espirito plastico e sympatico - eis o maior defeito do Visconde de Porto-Seguro"30.

Os méritos de Varnhagen, para Capistrano, enfatizados, sobretudo, na primeira parte do Necrológio, provêm das suas pesquisas documentais, que revelaram textos fundamentais para a escrita da história do Brasil, por vezes mediante edições conscienciosas, isto é, aquelas que, além do próprio texto, já de grande valor, trazem ainda um aparato crítico que aprofunda sua compreensão, como é o caso do Roteiro de Gabriel Soares de Sousa, que Porto Seguro editou pelo Instituto Histórico em 1851. Mais do que um grande pesquisador de arquivos, foi Varnhagen um precursor de novos temas na historiografia, superando abordagens superficiais. Porque ele, segundo Capistrano,

não se limitou a dar o rol dos reis, governadores, capitães-móres e generaes; a lista das batalhas, a chronica das questiunculas e intrigas que referviam no periodo colonial. Attendeu sem duvida a estes aspectos, a uns porque dão meio util e empirico de grupar os acontecimentos, a outros, porque rememoram datas que são doces ao orgulho nacional, ou melhor esclarecem as molas que actuam sob differentes acções. Fez mais. As explorações do territorio, a cruzada cruenta contra os Tupis, o augmento da população, os começos da industria, as descobertas das minas, as obras e associações literarias, as communicações com outras nações, assumem logar importante em sua obra. ${ }^{31}$

Portanto, mais do que a divulgação de documentos, pré-condição básica para a escrita da História, Varnhagen superou uma forma de escrita que toca a superfície dos eventos e fixa-se nos grandes indivíduos, para atingir aspectos mais abrangentes da vida social. Vemos que, pelos temas destacados por Capistrano, Varnhagen foi por ele definido como precursor para a própria história que o autor cearense viria a escrever. O estudo do território e da população, marcas da produção capistraneana, destacadas inclusive no texto de Sérgio Buarque de Holanda, que iremos abordar no próximo tópico, é aqui remetido ao Visconde de Porto Seguro.

Contudo, segundo Capistrano, faltavam ainda a Varnhagen aspectos decisivos que constituiriam o trabalho do historiador; do historiador "moderno", considerando-se as características que reúne Capistrano em sua análise, isto é, dimensões do olhar sociológico, da erudição histórica e da moderna experiência do tempo. Enfim, Porto Seguro não possuía

30 Idem, ibidem, p. 138.

31 Idem, ibidem, p. 136-137. 
a "objetividade necessária", e, mais do que isso, faltavam-lhe o atributo da compreensão e o domínio da sociologia contemporânea (ou seja, a sociologia oitocentista, de Comte e Spencer). A primeira lhe permitiria um relato mais "simpático" do processo histórico; não mais favorável, mas sim menos anacrônico. Parece-nos ser o senso de distância, a diferença histórica, traço do conceito moderno de história, uma das formas da nova relação com o tempo, que Capistrano evoca aqui. Por sua vez, a sociologia do século XIX, o "seculo de Comte e Herbert Spencer" ${ }^{2}$, permitiria a Varnhagen o efetivo salto para além da superfície da história: o salto para seu segredo íntimo. "Inspirado pela theoria da evolução, [que o historiador que a possuir] mostre a unidade que ata os tres seculos que vivemos. Guiado pela lei do consensus, mostrenos o rationale de nossa civilização, aponte-nos a interdependência organica dos phenomenos, e esclareça uns pelos outros" ${ }^{\text {33 }}$; pede Capistrano ao fim do Necrológio, ao indicar como deve proceder o historiador que assumir o lugar de Varnhagen na tarefa de escrever uma história geral do Brasil.

Não se trata mais de aprender as lições do passado: de produzir, como escrita da história, uma coleção de exemplos, mas de estudar um passado diverso do presente, desconhecido, mas dotado de lógica, de uma racionalidade que, essa sim, desemboca no presente, revelando também a sua estrutura íntima. Fernando Nicolazzi sugere, a partir da crítica de Capistrano citada acima, certa passagem da história filosófica à francesa que os membros do IHGB defendiam, para algum tipo de "síntese sociológica", característica da recepção brasileira do cientificismo. Nessa passagem, por sua vez, ocorreria uma separação entre escrita e método, entre narrativa e erudição, que possibilitaria, para outros autores, a emergência de um gênero como o ensaio histórico ${ }^{34}$. Capistrano, no entanto, esquiva-se da "síntese", ou ao menos a protela, até a conclusão de estudos particulares suficientes sobre diversos pontos ainda pouco conhecidos. De algum modo, o próprio Necrológio apresenta alguns pressupostos dessa escolha fugidia. Vale dizer ainda, retomando proposição de Valdei de Araújo, que é um dos traços do “cronótopo moderno" a percepção de que a geração anterior não foi moderna o suficiente, daí a busca de uma constante e necessária superação ${ }^{35}$; postura que pode ser vista no Capistrano do Necrológio, em relação a Varnhagen.

$3^{2}$ Idem, ibidem, p. 140.

33 Idem, ibidem, p. 140. Apesar da diferença temporal, conceitual e de vocabulário, a passagem acima nos faz recordar a seguinte passagem de R. Koselleck: "A forma mais adequada para se apreender o caráter processual da história moderna é o esclarecimento recíproco dos eventos pelas estruturas e vice-versa" (KOSELLECK, Reinhart. op. cit., p. 139).

34 NICOLAZZI, Fernando F. O ensaísmo no Brasil (mimeo).

35 ARAÚJO, Valdei Lopes de. A experiência do tempo: conceitos e narrativas na formação nacional brasileira (1813-1845). op. cit. 
Varnhagen publicou a primeira edição da História geral do Brasil em dois volumes entre 1854 e 1857. A obra, dedicada ao imperador D. Pedro II, não foi bem recebida inicialmente. Depois de novas pesquisas e constantes revisões que levaram mais de vinte anos, em 1877, o autor publicou a segunda edição. Para Lúcia Paschoal Guimarães, o Necrológio de Capistrano acabou sendo muito importante para que a obra de Varnhagen ganhasse o prestígio que desfrutaria. Segundo a autora, o Visconde de Porto Seguro era adepto das regras estabelecidas pelo historismo alemão; o historiador deveria se concentrar nos fatos que efetivamente ocorreram e estabelecer a verdade deles, por meio da erudição e da crítica das fontes. Desde 1838, o IHGB vinha construindo a memória do Brasil. Porém, tratava-se de uma "memória marcada pelo traço da continuidade" com o Império Português ${ }^{36}$. Segundo Manoel Guimarães, sendo um “momento mesmo de passagem, esta historiografia [do IHGB] abriga aspectos de uma visão antiga e de uma visão moderna de se pensar a história”. A história é percebida, ao mesmo tempo, como marcha linear e progressiva que articula futuro, presente e passado; e é essa concepção que possibilitaria a aprendizagem pragmática da experiência passada. Intelectuais como Varnhagen, "não se furtava[m] a prestar consultas e a elaborar pareceres para órgãos do Estado Imperial, na qualidade de historiador[es]". A história passou a legitimar uma série de "decisões de natureza política, mormente aquelas ligadas às questões de limites e fronteiras, vale dizer, aquelas ligadas à identidade e singularidade física da Nação em construção" ${ }^{\text {”77 }}$.

A nosso ver, o Necrológio de Francisco Adolfo de Varnhagen é fundamental, pois sistematiza uma série de experiências do tempo nas quais se percebe que a história é, em grande medida, reconstrução, no presente, da experiência única e múltipla no tempo, a partir da pesquisa empírica ${ }^{38}$. Essas considerações, sobre a importância da pesquisa documental e do

36 GUIMARÃES, Lúcia M. P. Francisco Adolfo de Varnhagen: a História geral do Brasil. In: MOTA, Lourenço Dantas (Org.). Introdução ao Brasil: um banquete no trópico 2. São Paulo: SENAC, 2001. p. 95-96. Ver, também, CEZAR, Temístocles. Como deveria ser escrita a história do Brasil no século XIX. Ensaio de história intelectual. In: PESAVENTO, Sandra. (Org.). História cultural: experiências de pesquisa. Porto Alegre: Editora da UFRGS, 2003; . O poeta e o historiador. Southey e Varnhagen e a experiência historiográfica no Brasil do século XIX. História Unisinos, v. 11, p. 306-312, 2007. GUIMARÃES, Manoel Luís Salgado. Nação e civilização nos trópicos: o IHGB e o projeto de uma História nacional. Estudos Históricos, Rio de Janeiro, n. 1, jan. 1988, p. 15. Para uma análise deste "momento de passagem" posterior ao clássico texto de Manoel Salgado Guimarães ver, sobretudo, ARAÚJO, Valdei L.; PIMENTA, João Paulo G. História (conceito de). In: JÚNIOR, João Feres. (Org.). Léxico da história dos conceitos políticos do Brasil. Belo Horizonte: Editora da UFMG, 2009. p. 119-140.

38 Trata-se, nesse ponto, de uma complexa tentativa de dissociação da história da memória. A respeito das relações entre memória e história, ver RICOEUR, Paul. $A$ memória, a história e o esquecimento. Campinas: Editora da Unicamp, 2007. 
contato com as fontes primárias, os conhecimentos teóricos necessários ao historiador, a postura do historiador diante de fatos e personagens do passado, entre outros pontos, remetem, essencialmente, na nossa leitura, às práticas que permitem tal recriação. Capistrano lamentava que Varnhagen desconhecesse o corpo de "doutrinas criadoras", as quais, nos últimos anos, denominavam-se sociologia. "Sem esse facho luminoso, elle não podia ver o modo por que se elabora a vida social. Sem elle as relações que ligam os momentos successivos da vida de um povo não podiam desenhar-se em seu espírito de modo a esclarecer as differentes feições e factores reciprocamente" 39 . Para Capistrano, era preciso escrever a história do Brasil "digna do seculo de Comte e Herbert Spencer" a fim de arrancar "das entranhas do passado o segredo angustioso do presente", e libertarnos do "empirismo crasso em que tripudiamos" $"$. Não mais se extraem do passado lições para o presente, mas sim seu "segredo angustioso". Para Capistrano, seria necessária, assim, uma teoria para interpretar o passado em sua singularidade, manifestada por meio dos fatos, ou, talvez, revelar a sua "evolução" orgânica e necessária.

Capistrano compreendeu o cerne da tensão epistemológica que constitui a complexidade do conhecimento histórico; nos termos de Koselleck, ser capaz de "fazer afirmações verdadeiras e, apesar disso, admitir e considerar a relatividade delas" história, história não poderá jamais ser deduzido a partir das fontes. Para que estas finalmente falem, faz-se necessária uma teoria da história possível”. Há, assim, uma “tensão entre a construção do pensamento teórico sobre história e a crítica das fontes. Uma é completamente inútil sem a outra"42. Pensamento teórico e crítica de fontes são duas dimensões complementares, em constante tensão. Capistrano percebeu a referida ambiguidade; porém, acreditava que a interpretação é dissociada da crítica das fontes $^{43}$. Para Koselleck, trata-se de um processo dinâmico ${ }^{44}$. Além disto, a

39 ABREU, João Capistrano de. Necrológio de Francisco Adolfo de Varnhagen. In: Ensaios e estudos: crítica e história. op. cit., p. 139.

40 Idem, ibidem, p. 140.

41 KOSELLECK, op. cit., p. 161.

42 Idem, ibidem, p. 188.

43 ARAÚJO, Ricardo Benzaquen de. Ronda noturna: narrativa, crítica e verdade em Capistrano de Abreu. op. cit., em especial p. 34: "Como se vê, o estabelecimento dos fatos parece representar para Capistrano uma etapa completamente distinta da interpretação, esta sim, orientada por leis e regras derivadas da sociologia”. Benzaquen refere-se à tese sobre o descobrimento do Brasil, escrita cinco anos após o Necrológio, que valeu a Capistrano a entrada no Colégio Pedro II.

44. A questão da teoria e da empiria em Capistrano é marcada pelo debate acerca da relação entre cientificismo e historismo em sua obra. Arno Wehling defende que, após 1880, Capistrano passa a se afastar do cientificismo, marcando sua produção menos 
dimensão da teoria para Capistrano não tem uma função relativista, como tem, por exemplo, para Koselleck; aparece, no Necrológio, com o sentido de revelar as leis da história. No entanto, o importante é destacar que Capistrano compreende, ao enfatizar a importância da relação entre teoria e empiria, dimensões da complexidade do conceito moderno de história e, sobretudo, do fazer histórico ${ }^{45}$.

pela teoria sociológica oitocentista e mais pela pesquisa empírica (WEHLING, Arno. Capistrano de Abreu: a fase cientificista. Revista do Instituto Histórico e Geográfico Brasileiro, n. 311, p. 43-91, 1976). José Honório Rodrigues, por sua vez, aponta evolução semelhante, marcando a entrada na Biblioteca Nacional, em 1879, como ponto inaugural do predomínio da empiria no trabalho de Capistrano e a tendência para o pensamento historista alemão (ABREU, João Capistrano de. Correspondência de Capistrano de Abreu. Edição organizada e prefaciada por José Honório Rodrigues. Rio de Janeiro: Civilização Brasileira; Brasília: INL, 2 ed. v. I 1977. p. XL-XLII). O texto que analisamos, portanto, pertenceria ainda à fase "cientificista" de Capistrano. Cremos que, embora existam diferenças visíveis entre os primeiros textos publicados de Capistrano, nos anos 1870 , e a produção, principalmente historiográfica, das décadas seguintes, a demarcação dessas "fases" necessita explicar a permanência de determinadas ideias e concepções em seu pensamento, mesmo após maior contato com as fontes (explicitar melhor esse ponto fugiria de nossos propósitos aqui - deixamos apenas a sugestão, indicando que A. Wehling apontou as divergências, entre os comentadores de Capistrano, a respeito de ruptura ou permanència em sua obra; WEHLING, Arno. Capistrano de Abreu - a fase cientificista. op. cit.). Acreditamos que tanto o termo "cientificismo" quanto o termo "historismo" apresentam problema semelhante: agrupam diversas tendências e autores, e, num olhar menos minucioso, podem sugerir univocidade. Arno Wehing aproxima Capistrano de Abreu e Sérgio Buarque de Holanda a partir do conceito de tradição hermenêutica: "diferente de Gilberto Freyre, Caio Prado Jr. ou Roberto Simonsen, Sérgio Buarque inseriu-se na tradição hermenêutica que teve, como seu antecessor imediato, o 'segundo Capistrano', aquele dos amadurecidos textos dos Capitulos de história colonial e Caminhos antigos e povoamentos do Brasil, não apenas pela aproximação temática, mas pela fundamentação teóricometodológica" (WEHLING, Arno. Notas sobre a questão da hermenêutica em Sérgio Buarque de Holanda. In: EUGÊNIO, João Kennedy; MONTEIRO, Pedro Meira. Sérgio Buarque de Holanda: perspectivas. op. cit., p. 394). Nossa hipótese de trabalho aqui recai sobre uma experiência comum do tempo, uma nova forma de articular passado, presente e futuro vivenciada a partir de fins do século XVIII. Nesse sentido, as correntes ditas "cientificistas" e as "historistas" compartilham dessa mesma experiência; fundamentalmente, do conceito moderno de história, ou fazem parte dele: são produto e produtoras desse conceito. Desse ponto de vista, o debate a respeito de Capistrano não impede nossa investigação.

45 Sobre a relação entre pesquisa empírica e escrita em Capistrano de Abreu, ver: OLIVEIRA, Maria da Glória. Crítica, método e escrita da história em João Capistrano de Abreu (I853-1927), 183 fl. Dissertação (Mestrado em História), Universidade Federal do Rio Grande do Sul, 20o6. Da mesma autora, ver também . A anotação e a escrita: sobre a história em capítulos de João Capistrano de Abreu. História da historiografia (revista on-line), n. 2, p. 86-99, março de 2009. 


\section{O pensamento histórico no Brasil nos últimos cinquenta anos : Necrológio de Capistrano? ${ }^{46}$}

Analisando os livros Um estadista do Império, publicado entre 1897 e 1899, de Joaquim Nabuco, e D. João VI no Brasil, publicado em 1908, de Oliveira Lima, Sérgio Buarque de Holanda afirmou, em O pensamento histórico no Brasil nos últimos cinquenta anos, artigo de 1951, que não faltou naquele último meio século obras históricas sobre o passado escritas a partir da atividade de um indivíduo. O livro de Nabuco "oferece-nos um opulento painel do segundo reinado, onde o calor e a devoção filial não chegam a perturbar a visão nítida do historiador"; ao passo que a obra de Lima, "Escrita necessariamente com outro espírito, e principalmente com as vantagens - e as desvantagens - da maior distância no tempo", continua sendo o mais amplo estudo sobre o "Brasil Reino"47. Podemos propor, talvez, leitura semelhante para o próprio artigo de Sérgio Buarque de Holanda, enquanto análise da historiografia brasileira a partir da obra seminal de um autor: Capistrano de Abreu.

46 Este artigo também foi analisado por Lúcia M. P. Guimarães, na conferência "A propósito do centenário de Sérgio Buarque de Holanda”, disponível em www.rj.anpuh.org/ Anais/2002/Conferencias/Guimaraes\%2oLúcia\%20M\%2oP.doc. Acesso em dez. 2008. A autora observa, notadamente, a relação entre Sérgio Buarque de Holanda e Capistrano de Abreu a partir do artigo, em função de suas ligações com o historismo alemão e das conexões entre a produção de ambos os estudiosos. Trata-se de obras de Sérgio Buarque, como Monções ou Caminhos efronteiras (essa última, composta de monografias, escritas por volta da época em que foi publicado o texto: $O$ pensamento histórico no Brasil durante os últimos cinquenta anos, que não só recuperavam temáticas a que dedicou grande atenção Capistrano (a ocupação e povoamento do interior), como também ressaltavam sua forma de abordá-las (por meio da cultura material e da vida cotidiana), conforme bem observa Lúcia Guimarães. Sobre o historismo no pensamento de Sérgio Buarque de Holanda, ver: DIAS, Maria Odila Leite da Silva (Org.). Sérgio Buarque de Holanda. São Paulo: Ática, 1985 (Coleção Grandes Cientistas Sociais, n. 51) e a conferência citada na nota abaixo, além, fundamentalmente, do texto do próprio Sérgio Buarque sobre Ranke: HOLANDA, Sérgio Buarque de. O atual e o inatual em Leopold von Ranke. In: .(Org.), Ranke. São Paulo: Ática, 1979. p.8 (Coleção Grandes Cientistas Sociais, n. 8). Também a tese de doutoramento de GONTIJO, Rebeca. $O$ velho vaqueano: Capistrano de Abreu, da historiografia ao historiador. Niterói: UFF, 2006, contém uma análise sobre a importância dada por Sérgio Buarque a Capistrano no artigo de 1951. A autora procura, principalmente, apontar a forma como Capistrano foi tomado como referencial pela historiografia do século XX, resultado inclusive da memória constituída desse historiador (processo iniciado ainda durante sua existência, e muito bem estudado na tese). Desse modo, Gontijo mostra as características que possuiria Capistrano (pessoais e de trabalho), que passaram a ser entendidas como pressupostos do historiador em geral (cf., em especial, p. 269-272).

47 HOLANDA, Sérgio Buarque. O pensamento histórico no Brasil nos últimos cinquenta anos. In: EUGÊNIO, João Kennedy; MONTEIRO, Pedro Meira. Sérgio Buarque de Holanda: perspectivas. op.cit. p. 6o8-6o9. 
Isso porque é a Capistrano que Sérgio Buarque remete o desenvolvimento da historiografia brasileira no meio século analisado, logo nos primeiros parágrafos do artigo. Cabe aqui, portanto, investigar as razões dessa consideração. Capistrano é apresentado por Sérgio Buarque, no início de seu texto, como o ponto inaugural de boa parte dos estudos que viriam a ser feitos naqueles cinquenta anos. O restante do artigo é dedicado à análise de estudos, organizados mais por tema (como biografias, ou estudos regionais) que dispostos em ordem cronológica, e acompanhados da crítica de Sérgio Buarque, a qual visava também assinalar as tendências gerais que marcaram a bibliografia naquele período. Observemos, pois, a leitura de Sérgio Buarque de Capistrano de Abreu e da historiografia brasileira no espaço de tempo delimitado por seu artigo.

Sérgio Buarque destaca os estudos regionais produzidos no meio século que analisava, bem como estudos sobre temas específicos da história do Brasil, como os jesuítas, ou a Guerra do Paraguai. A ocupação da terra também não foi problema estranho aos trabalhos históricos desse período, e documentos foram publicados com rigoroso aparato crítico, ampliando o acesso às fontes. Conforme Sérgio Buarque de Holanda, Capistrano é ponto inaugural de muitos desses esforços:

Com algumas reservas, talvez, na parte que se relaciona às campanhas sulinas do Império, o interesse por todos esses diferentes problemas que, através deste meio século, puderam ser melhor esclarecidos - descobrimento e ocupação da terra, atividade dos jesuítas e conquista do sertão -, deveu muita coisa, sem dúvida, à ação estimulante de Capistrano de Abreu. ${ }^{48}$

Entretanto, "Independentemente desse estímulo, não faltaram, é certo, as tentativas muitas vezes laboriosas, mas fundadas num critério de apresentação sobretudo cumulativa dos fatos históricos”, isto é, tentativas de se escrever uma história geral do Brasil ${ }^{49}$. Sérgio Buarque cita, nesse momento do texto, as obras de Rocha Pombo e João Ribeiro. O primeiro cabe especialmente na descrição dada acima, da historiografia "cumulativa dos fatos históricos"; o segundo, porém, trouxe contribuição importante para os estudos históricos: sua obra História do Brasil, destinada ao ensino superior, segue um plano, uma estrutura e um sistema de exposição, o que diferencia sua síntese das demais. A teoria, portanto, traria essa diferença. De qualquer modo, o contraste feito no artigo é entre os trabalhos

48 Idem, ibidem, p. 607 .

49 Idem, ibidem, p. 608. 
específicos sobre questões relevantes de nossa história ("descobrimento e ocupação da terra, atividade dos jesuítas e conquista do sertão”, por exemplo), pensadas a partir de uma visão teórica que lhes atribua valor (no caso de Capistrano, profundamente informada pela geografia e por teorias sociológicas que lhe deram, nas palavras de Sérgio Buarque, "uma sensibilidade aguçada à importância de ação dos fatores cósmicos - da terra, do meio e do clima - sobre as instituições humanas") ${ }^{50}$, e as sínteses fundadas num critério de exposição cumulativa dos fatos históricos.

Estudos regionais e estudos focados em indivíduos foram também vistos por Sérgio Buarque. Ao chegar aos primeiros estudos sociológicos, reaparece a questão da síntese. $\mathrm{O}$ autor destacou Populações meridionais do Brasil, de Oliveira Vianna, como obra também de historiador. Vianna, segundo Sérgio, popularizou o gênero do ensaio interpretativo, já empreendido com sucesso por Euclides da Cunha, em Contrastes e confrontos e À margem da História. Esse tipo de ensaio recorre ao trabalho histórico. Um marco desse gênero é o trabalho de Gilberto Freyre, que, com seu Casa-grande \& senzala, de 1933, deu "Novo e generoso impulso aos estudos interpretativos, com base em amplo material histórico"51.

"A bibliografia histórica do decênio de [19]30 é largamente ocupada por escritos onde a interpretação elucidativa, e às vezes interessada e mesmo deformadora dos fatos, visa a explicar tais fatos ou a caracterizá-los em sua configuração especificamente nacional”, escreve Sérgio, ressaltando, porém, a importância desses trabalhos, surgidos em "uma época de crises e transformações", e o fato de que ajudaram a dar nova direção aos estudos históricos ${ }^{52}$. Cita como exemplo, abstendo-se de um estudo intensivo de todas as obras, o que fugiria aos propósitos de seu artigo, Retrato do Brasil, de Paulo Prado, autor que pertenceria à "escola Capistrano"5̋. Sérgio Buarque atentou, por outro lado, para os estudos de inspiração totalitarista, numerosos também, segundo ele, nos anos 1930, mas que "mal interessam, em sua generalidade, à pesquisa historiográfica".

Para o autor, "Mais interessantes, por todos os aspectos, são sem dúvida as tendências de explicações de paisagens regionais" ${ }^{54}$. Ainda assim, voltamos a ter interpretações psicológicas e sociais gerais do Brasil, como em O conceito de civilização brasileira (1936), de Afonso Arinos de Melo Franco; A cultura brasileira (1943), de Fernando de Azevedo; e For-

50 Idem, ibidem, p. 602.

$5^{1}$ Idem, ibidem, p. 610.

$5^{2}$ Idem, ibidem, p. 611.

53 Aspas no original.

54 HOLANDA, Sérgio Buarque. O pensamento histórico no Brasil nos últimos cinquenta anos. op.cit., p. 611. 
mação da sociedade brasileira (1944), de Nelson Werneck Sodré. Aqui, afirmou Sérgio Buarque que,

por menos que esses trabalhos devam inscrever-se na literatura historiográfica, tomada a palavra stricto sensu, é forçoso admitir-se que participam de uma tendência que se reflete vivamente em outras obras da mesma época, onde a interpretação pessoal, endereçada a um alvo determinado, cede passo ao puro esforço de elucidação;

isto é, estas obras não podem ser agrupadas com aquelas em que as intenções do autor distorcem os fatos - a "interpretação pessoal" aqui não prevalece sobre a "elucidação"

Entretanto, os ensaios interpretativos, de forma geral, na caracterização de Sérgio Buarque, têm em comum o fato de se distanciarem do que é propriamente a produção historiográfica (stricto sensu), mesmo que (ou quando) baseados nas fontes usadas pelos historiadores, ou valendo-se de reconstruções históricas ${ }^{56}$. Os trabalhos monográficos parecem estar mais próximos do que efetivamente seria historiografia. Na categoria dos estudos regionais, porém, devemos lembrar que um estudo regional não é necessariamente um estudo monográfico, o que leva à consideração de que as noções de geral (lugar da síntese) e de particular (lugar da monografia)

55 Idem, ibidem, p. 612.

56 Para Fernando Nicolazzi, a historiografia entre 1870-1940 "se encontrava diante de uma dupla demanda: de um lado, realizar a síntese interpretativa sobre a formação da nação brasileira, tarefa encampada sobretudo pela história literária tal como praticada por Silvio Romero e, de outro, corrigir as falhas nos aspectos da erudição crítica da geração anterior, tarefa propriamente da história stricto sensu. Capistrano de Abreu é autor cuja noção de história permite reforçar este argumento". O gênero ensaístico de interpretação histórica está, assim, relacionado com "a demanda por uma espécie de síntese histórico-sociológica da nação, que vem suplantar, amparada pela assimilação de todo um instrumental teórico renovado (naturalismo, evolucionismo, positivismo, etc.), os princípios da 'história filosófica' que orientaram em grande parte a escrita da história no Brasil imperial; a consciência, motivada pela desilusão com a república instaurada no país e também pela realidade social brasileira, de uma crise na ordem do tempo que vai gerar todo um topos sobre o 'atraso nacional', como se o Brasil estivesse em desarmonia com o movimento histórico moderno. O ensaio histórico é uma resposta plausível para essa situação. A partir dos anos 1950, todavia, evidencia-se uma crítica contundente dirigida à tradição ensaística das décadas precedentes, motivada, sobremaneira, pela institucionalização das ciências sociais no Brasil. Exemplo claro disso é a postura de Florestan Fernandes ao longo da década, em seu esforço por estabelecer os parâmetros definidores da sociologia científica dentro da universidade". NICOLAZZI, Fernando F. O ensaísmo no Brasil (mimeo). Ver, também, NICOLAZZI, Fernando F. Um estilo de história: a viagem, a memória, o ensaio. Sobre Casa-grande \& senzala e a representação do passado. Tese de Doutorado. Universidade Federal do Rio Grande do Sul, 2008. 
são relativas. A história de São Paulo, por exemplo, também é um estudo geral, abrangendo particulares como os bandeirantes ou os capitães gerais. Quando dissemos anteriormente que Sérgio Buarque apontou os estudos regionais como mais interessantes que os ensaios interpretativos, omitimos que ele citou, entre seus exemplos de estudos regionais, Cassiano Ricardo e seu Marcha para o oeste, o qual caracterizou como análogo à pesquisa de Gilberto Freyre em Nordeste. Contudo, no trecho supracitado, Sérgio Buarque fez menção a uma "tendência" da época que discutia (os anos 1930 e 1940, imediatamente anteriores ao momento em que escreve), voltada para o "puro esforço de elucidação". Interpretações subjetivas estariam dando lugar a análises mais objetivas e localizadas, sem os mesmos propósitos das primeiras, visando simplesmente o esclarecimento de pontos de nossa história. Logo, para esse caminho estariam apontando os estudos históricos no Brasil, naquele instante. Percebe-se que já não havia, em 1951, "espaço” para grandes ensaios e sínteses, apesar da importância que tais trabalhos tiveram em seu tempo ${ }^{57}$.

Quando passou aos recentes estudos de história econômica, comentando os trabalhos de Caio Prado Jr. e Roberto Simonsen, Sérgio Buarque apontou que

É inevitável pensar-se, hoje, que a abordagem dessas questões só será realizável através de um trabalho prévio empreendido por diferentes especialistas que se dediquem, cada qual, a determinada época e a determinados problemas, não por meio de outras sínteses onde o particular tende a esfumar-se e a perder-se em proveito de alguma ilusória visão de conjunto. ${ }^{58}$

Para Sérgio Buarque de Holanda, assim como para Capistrano de Abreu quase setenta anos antes, a abordagem de determinadas questões históricas passa pela realização de diversas monografias, que atentem

57 No prefácio à reedição de Caminhos e fronteiras, Fernando A. Novais destaca que essa obra, primeiramente publicada em 1957, "é vista como a passagem da 'sociologia' para a 'história', e do ‘ensaísmo' para a 'pesquisa'”. Apesar das aspas, Novais parece corroborar tal visão, pois, após sugerir uma leitura da obra sergiana que enfatize sua unidade, apontou que, no caso de Caminhos e fronteiras, "Trata-se agora de uma análise vertical, num segmento específico daquele imenso conjunto" (grifo nosso). NOVAIS, Fernando A. Prefácio. In: HOLANDA, Sérgio Buarque de. Caminhos e fronteiras. São Paulo: Companhia das Letras, 1994, p.7-8. Vale dizer que essa obra reúne estudos de caráter monográfico, escritos por Sérgio Buarque nos anos 1940 e 1950; portanto, contemporâneos do artigo que analisamos.

58 HOLANDA, Sérgio Buarque. O pensamento histórico no Brasil nos últimos cinquenta anos. op.cit., p. 614 . 
para a particularidade do que é estudado, colocando em questão a obra de síntese. Dessa maneira, o "trabalho prévio", acima exigido para a história econômica, põe em suspensão a realização da síntese ${ }^{59}$. Para Holanda, as pesquisas necessárias deveriam se dar por intermédio da "utilização dos métodos que se vêm desenvolvendo em países onde existe longa tradição de estudos históricos especializados" ${ }^{90}$. O domínio desses métodos viria da transmissão dos conhecimentos necessários por meio, principalmente, das universidades, reforçadas pela presença de professores estrangeiros ${ }^{61}$.

\section{O conceito moderno de história e o progresso do conhecimento}

A grande importância atribuída a Capistrano de Abreu, no texto de Sérgio Buarque de Holanda, no desenvolvimento da historiografia brasileira ao longo da primeira metade do século $\mathrm{XX}$, foi, em larga medida, descrita em pontos análogos aos que Capistrano usara para salientar a importância de Varnhagen para a historiografia do século XIX, no Necrológio de 1878: a importância da pesquisa documental e o foco em novos temas históricos. Em outras palavras, os elogios de Sérgio a Capistrano lembram os

59 Nessa direção, o texto O pensamento histórico no Brasil nos últimos cinquenta anos é um bom indício daquilo que Fernando Nicolazzi, op. cit., denominou de crise e esgotamento do gênero ensaístico.

6o HOLANDA, Sérgio Buarque. O pensamento histórico no Brasil nos últimos cinquenta anos. op.cit., p. 614 .

61 Sérgio Buarque afirma: "no que se refere à história, inclusive à história do Brasil, em seus diferentes setores, foi certamente decisiva e continua a sê-lo, sobre as novas gerações, a ação de alguns daqueles mestres: de um Jean Gagé, por exemplo, e de um Fernand Braudel em São Paulo; de um Henri Hauser e de um Eugéne Albertini, na hoje extinta Universidade do Distrito Federal. [...]. Não parece excessivo acreditar, entretanto, que neles já se encontra o gérmen de um desenvolvimento novo e promissor dos estudos históricos no Brasil”. Idem, ibidem, p. 615. É preciso realçar que Sérgio Buarque de Holanda participou do projeto da Universidade do Distrito Federal, entre 1936 e 1939, sendo assistente do citado Henri Hauser, em História Econômica Contemporânea, e de Henri Tronchon, em Literatura Comparada. Para alguns analistas, entre eles, Luiz da Costa Lima, o livro Monções é um livro de "pura pesquisa histórica" e o "primeiro efeito de seu contato profissional com H. Hauser". LIMA, Luiz Costa. Sérgio Buarque de Holanda: Visão do Paraíso. In: EUGÊNIO, João Kennedy; MONTEIRO, Pedro Meira. Sérgio Buarque de Holanda: perspectivas. op.cit. p. 520. Ver, também, RODRIGUES, Henrique Estrada. Fronteiras da democracia em Sérgio Buarque de Holanda. Universidade de São Paulo (Tese de Doutorado), 2005. Thiago Lima Nicodemo oferece uma interessante reflexão sobre as questões da institucionalização e da profissionalização da história e da contribuição de professores estrangeiros no pensamento de Sérgio Buarque de Holanda, a partir do mesmo artigo que ora analisamos; cf. Urdidura do vivido: Visão do Paraíso e a obra de Sérgio Buarque de Holanda nos anos 1950. São Paulo: Edusp, 20o8. p. 193-195. 
de Capistrano a Varnhagen ${ }^{62}$. Além desses pontos destacados, Capistrano possuía maior objetividade, mantendo-se, segundo Sérgio Buarque, notavelmente impermeável a caprichos e interesses pessoais quando escrevia história, como escreveu o último no início do terceiro parágrafo de $O$ pensamento histórico. Sua formação teórica (autodidata, vale lembrar, pois Sérgio escrevia em momento em que as faculdades de Filosofia proporcionavam aparato significativamente diferente do que Capistrano e seus contemporâneos tiveram a seu dispor), remetida ao positivismo comteano e às doutrinas de Spencer, também diferencia sua produção e seu pensamento, embora não os determinem. Seu conhecimento da geografia e da antropogeografia alemãs contribuiu para acentuar a atenção aos fatores geográficos, que já vinham do conhecimento da sociologia oitocentista ${ }^{65}$.

Assim, divulgação de documentos (também segundo regras críticas), abertura de novas sendas para estudo, objetividade e domínio de conhecimentos teóricos e conceituais de outras disciplinas são os aspectos que caracterizam a produção histórica de Capistrano de Abreu, no texto de Sérgio Buarque de Holanda. Dessa forma, se observarmos que, para Capistrano, Varnhagen tinha entre suas qualidades a pesquisa documental e a descrição factual, mas lhe faltavam objetividade e teoria, Capistrano aparece, na visão de Sérgio Buarque, como dotado de todas essas qualidades, as presentes e as ausentes em Varnhagen. Se lembrarmos ainda que, no Necrológio, Capistrano parece propor, a partir das qualidades e defeitos de Varnhagen, um ideal de história e historiador, temos que esse ideal não é muito diferente em Capistrano e Sérgio Buarque (considerando que o primeiro quase o personifica, para o segundo).

Em ambos os textos sobre os quais nos debruçamos sobressai uma análise da produção historiográfica que não se limita aos dois autores privilegiados (Varnhagen, para Capistrano e o próprio Capistrano, para Sérgio Buarque de Holanda). Isso é mais forte no texto de Sérgio Buarque, evidentemente, porque é uma análise da historiografia brasileira na primeira metade do século XX. Capistrano não é o tema, é seu ponto de partida. No Necrológio, a análise da historiografia é, além de otimista (contrastando com outros registros, principalmente posteriores, de Capistrano $)^{64}$, centrada nas pesquisas particulares que viriam viabilizar

62 Lúcia M. P. Guimarães, na conferência que citamos acima, "A propósito do centenário de Sérgio Buarque de Holanda", assinala ainda que as qualidades vistas por Sérgio Buarque em Capistrano se assemelham às que Holanda apontou existirem em Leopold von Ranke.

63 HOLANDA, Sérgio Buarque. O pensamento histórico no Brasil nos últimos cinquenta anos. op.cit., p. 6o1-6o2.

64. Como em carta a João Lúcio de Azevedo, de 17 de maio de 1920, em que Capistrano afirma, a respeito da solidez das pesquisas até então feitas em história do Brasil: "A 
a escrita de uma nova História geral do alcance da história escrita pelo Visconde de Porto Seguro, com os avanços de concepção e conhecimento ocorridos desde a publicação daquela obra. Capistrano já definira, como vimos, o arcabouço teórico da obra: a sociologia oitocentista. Esperava então os resultados de várias pesquisas particulares. Conforme o autor,

Signaes de renascimento nos estudos historicos já se podem perceber. Publicações periodicas vulgarizam velhos escriptos curiosos, ou memorias interessantes esclarecem pontos obscuros. Muitas Provincias compõem as respectivas historias. Periodos particulares, como a Revolução de 1817, a Conjuração Mineira, a Independencia, o Primeiro Reinado, a Regencia, são tratados em interessantes monographias. Por toda parte pullulam materiaes e operarios; não tardará talvez o architecto. ${ }^{65}$

Capistrano não perderia de vista, ao longo da vida, a necessidade dos estudos de divulgação de documentos e de monografias para a escrita futura de uma nova síntese da história do Brasil ${ }^{66}$. No texto de Sérgio Buarque, além do mesmo otimismo, ao final, relacionado à contribuição das universidades e, principalmente, professores estrangeiros lecionando no país ${ }^{67}$, observamos uma constante relação entre sínteses e monografias. No seu caso, as sínteses têm ainda uma forma peculiar, característica dos anos 1930, os ensaios interpretativos (de que ele próprio

História do Brasil dá a idéia de uma casa edificada na areia. É uma pessoa encostarse numa parede, por mais reforçada que pareça, e lá vem abaixo toda a grampiola”. ABREU, João Capistrano de. Correspondência de Capistrano de Abreu, v. 2, edição organizada e prefaciada por José Honório Rodrigues. Rio de Janeiro: Civilização Brasileira; Brasília: INL, 2. ed., 1977. p. 161-162.

65 ABREU, Capistrano de. Necrológio de Francisco Adolfo de Varnhagen. Ensaios $e$ estudos: crítica e história, Priemira série. op. cit., p. 140.

66 O que assinala Guillermo Zermeño Padilla para o período pós-indendência na América Latina continuaria, então, válido para o período posterior; segundo o autor "En la medida en que el futuro no se manifieste, la experiencia moderna de la historia irá tomando el perfil de una permanente transición. La inestabilidad se compensará con la escritura de historias generales de la nación”. Porém, para Capistrano essa história deverá ser escrita no futuro e não mais no presente. ZERMEÑO PADILLA, Guillermo. Historia, experiencia y modernidad en Iberoamerica, 1750-1850. Almanack Braziliense [recurso eletrônico], São Paulo: Instituto de Estudos Brasileiros da Universidade de São Paulo, n. 7, maio de 2008.

67 Lembramos, novamente, a conclusão do artigo: "Não parece excessivo acreditar, entretanto, que neles [isto é, no que denomia os 'tipos de trabalho' produzidos neste meio universitário, como 'cursos especiais, seminários, teses de concursos'] já se encontra o gérmen de um desenvolvimento novo e promissor dos estudos históricos no Brasil.” HOLANDA, Sérgio Buarque. O pensamento histórico no Brasil nos últimos cinquenta anos. op.cit., p. 615 . 
fora expoente, embora tenha omitido do artigo o seu Raizes do Brasil), forma que o próprio Sérgio Buarque remete, entretanto, à geração de Capistrano, como vimos anteriormente (ao tratar de Oliveira Vianna e da obra Populações meridionais do Brasil, Holanda afirma sê-la exemplar do gênero já empreendido por Euclides da Cunha).

Sendo assim, surge uma questão: a atenção ao particular pressupõe regularidade ou singularidade dos fenômenos históricos? Segundo François Hartog,

na moderna concepção de história, a exemplaridade cede lugar ao unívoco. Algum dia, no futuro, alguém estabelecerá uma lei. $\mathrm{Ou}$, para empregar outra formulação típica de fins do século XIX, algum dia no futuro virá o dia glorioso da "synthèse", mas por enquanto "c'est l'ordinaire ingrat de l'analyse"! ${ }^{68}$

A síntese é resguardada para o futuro, para depois que todos os casos particulares, irredutíveis a qualquer padronização ou descrição por tendências que dispense seus estudos individuais, tenham sido conhecidos. O momento é de análise (literalmente, de separação em partes) para depois se elaborar a síntese.

A síntese, composta a partir de intenso levantamento documental, e após variados estudos monográficos, é parte da concepção historiográfica oitocentista. A história é, então, concebida como edifício construído sobre materiais (vimos Capistrano usar essa metáfora para a documentação); é uma grande criação coletiva que vai sendo completada com os trabalhos particulares. Daniel Mesquita Pereira, em sua tese sobre Capistrano de Abreu, apontou que a prática historiadora, no século XIX, é constituída pela ideia da acumulação de informação por meio da crítica documental. No século XIX, isso passou a ocorrer "numa escala tão avassaladora que tendia a cobrir uma 'história total'. As histórias parciais são vistas como etapas necessárias para a articulação de um enredo mais generalizante, ou, na fórmula de Koselleck, um singular coletivo". A possibilidade de reunir as histórias particulares era vista como natural, e as monografias, como uma etapa necessária nesse percurso. "Ligar num todo coerente uma sequência de acontecimentos é uma das funções da estrutura narrativa da historiografia moderna"69. Como resumiu Manoel Guimarães: "A História - coletivo singular - entendida segundo a nova

68 HARTOG, François. Tempo, história e a escrita da história: a ordem do tempo. $R e$ vista de História, n. 148, p. 13, primeiro semestre de 2003.

69 PEREIRA, Daniel Mesquita. Descobrimentos de Capistrano. A história do Brasil a "grandes traços e largas malhas". (Tese de Doutorado, PUC/RJ), 2002. p. 37. 
compreensão formulada pela Ilustração viria a se tornar a condição de possibilidade das histórias particulares"70.

A história não chega a ser conhecimento meramente cumulativo, havendo espaço para crítica e para re-escrita. Conforme sugeriu Maria da Glória de Oliveira, em dissertação de mestrado sobre Capistrano de Abreu, a noção de "reescrita da história" é pertinente "como modo de legitimação do projeto historiográfico de Capistrano”. Segundo a autora,

Embora se considere evidente que em razão de seu caráter investigativo a história seja continuamente "corrigida", a condição compulsória para a sua reescritura parece se estabelecer com o advento da concepção moderna de um tempo especificamente "histórico" [...] É a partir desta perspectiva, que o próprio saber histórico, em sua acepção científica moderna, assume um caráter tanto cumulativo quanto provisório, na medida em que, ao pressupor acréscimos, revisões e retificações, apresenta-se como processo infindável de acumulação/superação de "verdades" parciais e relativas. ${ }^{71}$

A este respeito, Valdei Lopes de Araújo afirma que para a primeira geração do acontecimento Independência, o levantamento de fatos é um procedimento suficiente, ao passo que, para a segunda geração, ele é regulador:

nos anos iniciais do IHGB foi possível notar a tensão entre as demandas por um levantamento exaustivo dos fatos herdeira de uma concepção de história ligada à crônica e à cronologia, e uma compreensão hermenêutica e narrativa que, mesmo dependente do estabelecimento factual, exigia uma abordagem seletiva e hierárquica dos eventos. ${ }^{72}$

70 GUIMARÃES, Manoel Luiz Salgado. Entre as luzes e o romantismo: as tensões da escrita da história no Brasil oitocentista. In: . (Org.). Estudos sobre a escrita da história. Rio de Janeiro: 7 Letras, 2006. p. 69 . O autor afirma ainda: "uma disciplina que tenha por objeto submeter o passado a procedimentos de conhecimento, à investigação empírica, para extrair dele conhecimento, supõe primeiramente que o passado tenha se transformado em História [...] a história na sua forma disciplinar deve ser considerada como apenas uma das inúmeras formas de elaboração significativa do tempo decorrido, como parte de algo mais amplo que chamaria de "cultura histórica como parte de uma cultura da lembrança”' (p. 7o). OLIVEIR A, Maria da Glória. Crítica, método e escrita da história em João Capistrano de Abreu (I853-1927). op. cit, p. 65.

72 ARAÚJO, Valdei Lopes. A experiência do tempo: conceitos e narrativas na formação nacional brasileira (1813-1845). op. cit., p. 187 . 
Essa busca de sentido era casada com a tentativa de monumentalização do presente finito. O Necrológio de Francisco Adolfo de Varnhagen mostra-nos claramente que a referida tensão atravessou a historiografia oitocentista. Não sem razão, Araújo aponta que o conceito de evolução só se torna dicionarizado em 1877-1878. Para o autor, "é apenas pelo conceito histórico de evolução que os vestígios de um tempo cíclico poderão ser substituídos por uma compreensão acumulativa e linear da história das civilizações"73.

Desse modo, a experiência do tempo que orienta a nova visão da relação entre presente, passado e futuro atinge o próprio conhecimento histórico, pautado agora por um horizonte de expectativa que prevê o acréscimo de novos conhecimentos e a revisão daqueles outrora estabelecidos, mediante novos progressos, como a descoberta de documentos inéditos ou a reinterpretação dos já conhecidos à luz de novas teorias ${ }^{74}$. Conforme observa Thiago Lima Nicodemo, no artigo $O$ pensamento histórico no Brasil nos últimos cinquenta anos, Sérgio Buarque de Holanda apontou ainda duas tendências nos estudos históricos brasileiros: uma que propõe remédios do passado para problemas do presente, e outra que procura "exorcizar" (segundo a metáfora que Nicodemo recupera de outros textos de Sérgio Buarque) o passado do presente, tirar o primeiro dos ombros do segundo, na expressão de Goethe, de que também se valeria Sérgio Buarque em outros momentos. Essa segunda tendência, exemplificada por Caio Prado Jr, segundo Holanda em $O$ pensamento histórico, pressupõe um interesse do historiador pela vida contemporânea e um comprometimento com um projeto de futuro, na linha do que outros autores vinham propondo desde o início do século, tais como Benedetto Croce, Marc Bloch, Lucien Febvre e Johan Huizinga, conforme observa Nicodemo ${ }^{75}$. Tratase de uma forma de pensar a história que não mais assume o passado como fonte de exemplos para o presente, que olha criticamente para esse passado, rejeitando sua monumentalização, como já vimos em Capistrano. Vale dizer que Sérgio Buarque comparou Capistrano a Marc Bloch no artigo, sob a chave de que o primeiro compreendia e praticava aquilo que o segundo viria a defender: que as fontes só falam se o historiador ousar

73 Idem, ibidem, p. 184. Ver também GUIMARÃES, Manoel Luiz Lima Salgado. Do litoral para o interior: Capistrano de Abreu e a escrita da história oitocentista. In: CARVALHO, José Murilo de; NEVES, Lúcia Maria Bastos Pereira das. (Orgs.). Repensando o Brasil do Oitocentos: cidadania, política e liberdade. Rio de Janeiro: Civilização Brasileira, 2oog. p. 267-292.

74. Analisando a reflexão de R. Koselleck sobre o conceito moderno de história, Paul Ricoeur afirmou: "existe tempo da história na medida em que há uma história una. É a tese mestra de Koselleck" (RICOEUR, Paul. op. cit., p. 313).

NICODEMO, Thiago Lima, op. cit. p. 187-195. 
"formular-lhes perguntas precisas e bem pensadas"; que antes de qualquer investigação, há um problema a mover o historiador ${ }^{76}$.

Capistrano de Abreu e Sérgio Buarque de Holanda, nos dois textos em questão, parecem manter uma visão parecida quanto à questão monografia-síntese: aguardam os estudos particulares, rejeitam sínteses precipitadas. Os dois autores apontaram a necessidade de estudos particulares, a partir da avaliação que fizeram de dois momentos específicos da história da historiografia brasileira (o fim do século XIX e a primeira metade do século XX), sem perder de vista a elaboração de uma história geral. Nos escritos dos dois autores, parece haver articulação entre as duas formas de escrita, mas para ambos, em momentos diferentes, a hora parecia ser das monografias.

Ainda que se possa encontrar regularidade entre os fenômenos históricos, para lhes dar seu caráter essencial, e, assim, sintetizar a história, a regularidade pode ser obtida no futuro a partir dos muitos estudos particulares, e não de uma lei geral. Mas, nos textos em questão, parece que a dimensão da reescrita da história e mesmo uma maior desconfiança em relação à síntese futura aparecem com maior clareza no texto de Sérgio Buarque de Holanda, sobretudo quando este afirmou, como vimos anteriormente, ao tratar da história econômica, que o desenvolvimento de seu conhecimento não viria "por meio de certas sínteses onde o particular tende a esfumar-se e a perder-se em proveito de alguma ilusória visão de conjunto". Importante também é a forma como o historiador apresenta este juízo: “É inevitável pensar-se, hoje”... Isso sugere um momento específico do desenvolvimento dos estudos históricos no Brasil, em que uma nova síntese é vista com cautela. No seu hoje (1951), o leitor perguntava-se pelos estudos monográficos, a cargo de "especialistas", pelo "trabalho prévio" à elaboração da síntese. Em Capistrano, há uma mais clara e esperançosa expectativa em relação à síntese futura, um olhar que já procura articular a produção dispersa, que se realiza na sua "atualidade" (no hoje de Capistrano, 1878), em uma obra única ${ }^{77}$.

76 HOLANDA, Sérgio Buarque de. O pensamento histórico no Brasil nos últimos cinquenta anos. op.cit., p. 602 .

77 Mas em ambos a elaboração da síntese parece ser pensada da mesma forma: dever-se-ia fazer a articulação de diversos trabalhos monográficos, que preenchessem as lacunas da história brasileira, isto é, que realizassem o estudo dos temas e problemas que compõem (ou deveriam compor) uma História geral do Brasil. Escapando brevemente ao escopo deste artigo, lembramos a obra coletiva História geral da civilização brasileira, que Sérgio Buarque começou a dirigir a partir de 1960, menos de dez anos após publicar o artigo que analisamos. O autor afirmou, na introdução ao primeiro volume: "A verdade, no entanto, está em que são de data recente e em número ainda relativamente escasso, as pesquisas e análises monográficas que poderiam fornecer apoio seguro a muitas tenta- 
Outra hipótese para o cruzamento entre os textos, que, se correta, pode ajudar a entender as semelhanças entre eles, é o fato de que ambos podem representar expressões da opção de seus autores pelos estudos históricos. Capistrano começa a largar os estudos de crítica literária e partir para a história - que ele não faria exclusivamente até o fim da vida, tendo em vista seus estudos de etnografia, geografia, etc. Sérgio Buarque de Holanda, por sua vez, em seu texto, já se definia claramente como historiador profissional ${ }^{78}$. Os dois textos podem ser lidos, assim, como expressões de uma opção pela história como campo de estudo, compartilhando, desse modo, alguns aspectos desta prática que ambos abraçam, mesmo separados no tempo: vivem contextos culturais, políticos e acadêmicos diferentes, mas uma similar experiência moderna de tempo e escrita da história. É necessário destacar, entretanto, que as posições de Capistrano após o Necrológio provavelmente mudaram mais que as de Sérgio Buarque depois de $O$ pensamento histórico. Embora haja também continuidades, é notável a progressiva diminuição do uso e da importância, nos escritos de Capistrano, da mesma sociologia oitocentista que o historiador cobrara de Varnhagen. Autores como Spencer e Comte passarão a aparecer cada vez menos em seus textos.

Se as observações acima forem corretas, o que ambos os textos trazem são definições de atributos centrais do fazer histórico moderno.

Em que pesem as diferenças de estilo, época, leitores e posicionamentos dos dois textos analisados (isto é, o diálogo contemporâneo

tivas de síntese. Lacunas e deficiências tornaram-se, por vêzes, inevitáveis na obra [...]”. In: História geral da civilização brasileira. t. 1, v. 1. Sob a direção de Sérgio Buarque de Holanda, assistido por Pedro Moacyr Campos, para os períodos colonial e monárquico, e por Boris Fausto, para o período republicano. Introdução geral de Sérgio Buarque de Holanda. São Paulo: Difusão Européia do Livro, 196o. p. 8. Certamente, a análise dessa obra permitiria uma abordagem mais aprofundada da síntese, do conceito de civilização e de história geral para Sérgio Buarque. Contudo, restringimo-nos aqui ao aspecto que se relaciona com as ideias do artigo de 1951. Sobre Sérgio Buarque de Holanda e a História geral da civilização brasileira, ver FAUSTO, Boris. Organizando a História geral da civilização brasileira. Estudos Históricos, Rio de Janeiro, n. 1, 1988, p. 162-166; CALDEIRA, João Ricardo de Castro. Sérgio Buarque de Holanda e a História Geral da Civilização Brasileira. Notícia bibliográfica e histórica. Campinas, n. 34 (187), p. 307-313, 2002. Vale dizer que o IHGB já trazia a noção de um projeto coletivo de história geral, em que cabia ao Instituto a coordenação deste esforço, articulando a coleta de documentos e a produção de monografias sobre temas específicos, conforme a análise de Manoel Luiz Salgado Guimarães do discurso do primeiro secretário perpétuo do IHGB, Januário da Cunha Barbosa, no ato de estatuir-se o Instituto, no texto de GUIMARÃES, Manoel Luiz Salgado. A disputa pelo passado na cultura histórica oitocentista no Brasil. In: CARVALHO, José Murilo de. Nação e cidadania no império: novos horizontes. Rio de Janeiro: Civilização Brasileira, 2007, em especial p. 103.

78 É interessante destacar que Holanda em 1947 foi contratado para assumir funções no Museu Paulista como "historiógrafo". Cf.: EUGÊNIO, João Kennedy; MONTEIRO, Pedro Meira. Sérgio Buarque de Holanda: perspectivas. op.cit., p. 690. 
específico em que se inserem), percebemos que há neles concepções próximas em relação ao tempo histórico e, sobretudo, ao fazer histórico. Por essa razão, como esperamos ter mostrado, os dois autores percebem e utilizam o conceito moderno de história procurando enfatizar dimensões que, do nosso ponto de vista, privilegiam a complexidade desse conceito. No entanto, ao que parece, ambos os autores defendem explicitamente posições que valorizam uma determinada escrita da história, aquela em que a empiria está articulada à teoria.

No caso do texto de Capistrano, talvez possamos dizer que a primeira parte do Necrológio contém os atributos que Varnhagen possuía: a pesquisa documental e a qualidade da leitura das fontes, que o tornava capaz de extrair delas datas e fatos para a composição da narrativa histórica. A segunda parte contém principalmente as que não tinha: espírito compreensivo e visão de conjunto. É preciso enfatizar que Varnhagen tinha uma visão de conjunto, mas não do tipo que depois de sua obra seria possível e desejável para a geração de Capistrano. Os dois textos que analisamos aqui são embasados pelo conhecimento de seus autores (Capistrano e Sérgio Buarque) da história da historiografia brasileira, que culmina, em ambos, no que está por fazer. Nessa direção, talvez possamos nos arriscar a dizer que Sérgio Buarque sintetiza a experiência de duas gerações (a do ensaísmo e a da história acadêmica, em sua consolidação) numa só vida. Essa experiência talvez seja diferenciada no caso de Capistrano, pois não havia ainda em seu horizonte a questão da institucionalização acadêmica. Desse modo, outra articulação possível relaciona-se a certo otimismo no final dos textos, como se, para os dois, em diferentes momentos, a historiografia brasileira estivesse no caminho certo, progredindo.

Como foi visto, Capistrano se apropria do conceito moderno de história em sua complexidade, dialogando com autores da tradição histórica e sociológica alemã, francesa e inglesa, sem que sua "modernidade" venha, por isso, de "influências estrangeiras". Pensamos que tanto Capistrano de Abreu como Sérgio Buarque de Holanda, são de difícil enquadramento em tradições historiográficas nacionais (embora ambos os textos analisados revelem o profundo conhecimento de seus autores da historiografia nacional brasileira, e mesmo, nos autores que destacam, certas "filiações", se se pode falar assim); e também nos ismos historiográficos (positivismo, cientificismo, historismo, marxismo, etc.) ${ }^{79}$. Talvez

79 Maria Odila Leite da Silva Dias o afirma, a respeito de Sérgio Buarque, em seu texto, Dialogando com Sérgio Buarque de Holanda. Cienc. Cult., São Paulo, v. 54, n. 1, 2002. Disponível em: <http://cienciaecultura.bvs.br/scielo.php?script=sci_arttext\&pid=Sooo9$67252002000100036 \& \operatorname{lng}=\mathrm{en} \& \mathrm{nrm}=\mathrm{iso}>$. Acesso em: $15 \mathrm{dez} .2008$. 
por isso ambos sejam "mestres do rigor" $"$, na expressão de Paul Ricouer, no que se refere à capacidade de compressão, explicação, interpretação e desenvolvimento do conceito moderno de história. Paul Ricoeur afirma, a partir de Koselleck, que no final do século XVIII e ao longo do século XIX houve um "estágio, que se pode qualificar de ingenuidade ou de inocência, [em que] o termo história exibe um teor realista que garante à história enquanto tal uma pretensão própria à verdade" ${ }^{81}$. A nosso ver, a riqueza dos dois textos analisados estaria justamente em perceber os limites desse tipo de concepção e em irem em direção a uma percepção mais complexa e mais rica, fruto da pesquisa e da (re)escrita da história. Capistrano e Sérgio Buarque não abandonaram uma concepção realista de história, ou sua pretensão à verdade. Mas ambos perceberam dimensões da complexidade dessa tarefa, na presença constante da reescrita, ou na perspectiva de que novos documentos e novas interpretações obriguem a uma revisão dos conhecimentos estabelecidos.

A releitura desses textos a partir do nosso presente coloca-nos diante de dilemas ainda não resolvidos. Podem ser mesmo tensões constitutivas da escrita da história. Nesse sentido, os dois autores foram mestres em explorar, ao limite, as potencialidades dessa escrita. Vislumbraram outras possibilidades, pois perceberam que a própria escritura e re-escritura da história é plural. Em ambos, haveria a preocupação com a relação entre síntese e estudo monográfico, teoria e empiria, objetividade e subjetividade, entre outras questões, que convergem para a formulação de um ideal de historiador e de caminhos para os estudos históricos, a partir do momento em que seus textos foram publicados, configurando-se como intervenções na historiografia de seu tempo.

De todo modo, gostaríamos de salientar que as referidas tensões e/ ou oposições relativas à forma como o conceito moderno de história foi pensado e utilizado permanecem ${ }^{82}$. Em entrevista recente, Maria Odila Leite da Silva Dias afirmou: "Estamos cansados de generalidades. A meu

8 Cf. RICOEUR, Paul. op. cit.

81 Idem, ibidem, p. 315 .

82 Muito provavelmente essas tensões e/ou oposições são fruto de uma contradição interna do conceito moderno de história apontada por Ricoeur, em seu diálogo com Koselleck, nos seguintes termos: "a depreciação do passado não bastaria para minar de dentro a afirmação da história como totalidade auto-suficiente se um efeito mais devastador não tivesse se acrescido a ela, a saber, a historização de toda a experiência humana. A valorização do futuro teria permanecido uma fonte de certeza se não tivesse sido acompanhada pela relativização de conteúdos de crenças considerados imutáveis. Talvez esses dois efeitos sejam potencialmente antagonistas, na medida em que o segundo - a relativização - contribui para minar o primeiro - a historização, até então acoplada a uma expectativa garantida por si mesma. É nesse ponto que a história do conceito de história desemboca numa ambigüidade que a crise do 
ver, não faz nenhuma falta uma síntese ou mais uma teoria do Brasil. [...]. É difícil pensar em fazer síntese quando ainda desconhecemos grande parte da história do Brasil". Para Emília Viotti da Costa, no entanto, “as grandes sínteses são essenciais para o conhecimento do passado e para a elaboração de um projeto político. Mais do que úteis, elas são necessárias" ${ }^{83}$. A esse respeito, em entrevista, em 2005, Reinhart Koselleck reafirmou as potencialidades do conceito moderno de história ao afirmar crer que "essa pluralização de história [também uma parte da experiência moderna, a seu ver] [...] prova a necessidade do coletivo singular 'história' como instrumento de análise"; ainda "que segue sendo pertinente o estudo das mudanças globais em escala universal" $"$. Esse debate atual, rapidamente aludido, mostra-nos a contemporaneidade do não-contemporâneo nos dois textos escolhidos como objeto de reflexão deste estudo.

historicismo levará ao primeiro plano, mas que é como que um efeito perverso do que Koselleck chama de historização do tempo" (Idem, ibidem, p. 319).

83 MORAES, José Geraldo Vinci de; REGO, José Marcio. Conversas com historiadores brasileiros. São Paulo: Editora 34, 2002. p. 208 (Maria Odila) e p. 88 (Emília Viotti). É preciso lembrar que, para Durval Muniz de Albuquerque Jr, um “traço constante da crítica historiográfica brasileira é a tendência a estabelecer maniqueísmos, a resumir a pluralidade do campo historiográfico a uma espécie de jogo dual, onde o leitor é conclamado a tomar partido por um dos lados litigiantes." ALBUQUERQUE JR, Durval M. O historiador naïf ou a análise historiográfica como prática de excomunhão. In: GUIMARÃES, Manoel Luiz Salgado (Org.). Estudos sobre a escrita da história. op. cit., p. 193. Pensamos que, de algum modo, Capistrano e Sérgio, nos textos analisados, procuraram ir além desse jogo.

84. Entrevista em http://www.institucional.us.es/araucaria/entrevistas/entrevista_l. htm. Acesso out. 2008. 


\section{Necrológio de Francisco Adolpho de Varnhagen, \\ Visconde de Porto-Seguro ${ }^{85}$}

A Pátria traja de luto pela morte de seu historiador, - morte irreparável, pois que a constância, o fervor e o desinteresse que o caracterizavam, dificilmente se hão de ver reunidos no mesmo indivíduo; morte imprevista, porque a energia com que acabara a reimpressão de sua História, o vigor com que continuava novas empresas, a confiança com que arquitetava novos planos, embebedam numa doce esperança de que só mais tarde nos seria roubado, depois de por algum tempo gozar do descanso a que lhe dava direito meio século de estudos e trabalhos nunca interrompidos.

Filho da nobre Província de São Paulo, iluminava-lhe a fronte a flama sombria de Anhanguera. O desconhecido atraía-o. Os problemas não solvidos o apaixonavam. Códices corroídos pelo tempo; livros que jaziam esquecidos ou extraviados; arquivos marcados com o selo da confusão, tudo viu, tudo examinou. Pelo terreno fugidio das dúvidas e das incertezas caminhava bravo e sereno, destemido bandeirante à busca de mina de ouro da verdade.

Muito moço, tivera de acompanhar o pai a Portugal e no exílio, ao hálito perfumoso da saudade, infiltrara-se-lhe um patriotismo profundo e casto. A Pátria aparecia-lhe suave e virginal, envolta em um nimbo vago e puro, como a memória de um ente amado, que não tornamos a ver, e pelos campos em que brincara, pelas matas, a cuja sombra, se acolhera, pelos céus, sob cuja cúpula abrira os olhos à luz da existência, eram as suas mais ternas e mais cordiais aspirações.

A essas aspirações veio dar nova força a campanha que fez sob as ordens do Duque de Bragança, o herói legendário que a seus olhos de férvido realista simbolizava a alma da Pátria. O estudo das ciências físicas que então cursava, não conseguiu concentrar em si o pensamento que, inquieto, almejava por outros objetos. Persistente, como já então nos

85 Publicado originalmente no Jornal do Commercio, de 16 e 20 de Dezembro de 1878 , e reproduzido em Apenso à Historia Geral do Brasil, de Varnhagen, tomo 1. ${ }^{\circ}$, ps. 502/508, 4. ed., 1927; ABREU, João Capistrano de. Ensaios e Estudos: crítica e história, ı. série. Rio de Janeiro: Livraria Briguiet, 1931; ABREU, João Capistrano de. Ensaios e estudos: crítica e história, ı. série, 2. ed. Rio de Janeiro: Civilização Brasileira; Brasília: INL, 1975. Aqui, utilizamos o texto da primeira edição dos Ensaios e estudos, 1931, com grafia atualizada. Agradecemos a Ítala Byanca Morais da Silva pelas informações sobre Capistrano de Abreu e o Necrológio. 
aparece, dominado pelo respeito do que considerava dever, pôde levar a termo o tirocínio acadêmico; porém, no cultivo das ciências, não era o esmero das observações, a beleza do método e das experiências, a força e o alcance das teorias e generalizações, que lhe despertavam o interesse ou incitavam a atividade; era a aplicação que de seus conhecimentos podia fazer à Pátria, o dia que projetava sobre as coisas nacionais.

Um livro existia, vasto como uma enciclopédia, interessante como um romance, fértil como um punhado de verdades, roteiro, corografia, história natural, crônica. Longo tempo inédito, fora afinal publicado pela Academia das Ciências, porém mutilado, anônimo, inçado de erros, eivado de incorreções.

Varnhagen determinou as posições geográficas, identificou as espécies biológicas, corrigiu os erros dos copistas e do escritor, provou a autenticidade do escrito de modo irrefragável, ao mesmo tempo que descobriu o nome do autor - Gabriel Soares de Sousa.

Grande parte das Reflexões críticas sobre o livro deste - o primeiro trabalho que imprimiu - perderam a atualidade em consequência de novos estudos posteriores, em que ninguém entrou com capital maior que o dele. Quando foram publicadas produziram o efeito de uma revelação, abriram um mundo novo às investigações de todos aqueles que se ocupavam de nossos anais.

Essa obra e a que de colaboração escreveu sobre a Corografia caboverdiana mostram-no indeciso, flutuando entre as ciências positivas e a história. À história pertencem todas as outras publicações suas; a contar do Diário da navegação de Martim Afonso, preito rendido a São Paulo, na pessoa do povoador e primeiro donatário da capitania.

Depois, embarca para o Brasil, e durante o tempo que aqui demora, comunica ao Instituto o fogo que o abrasava. Percorre a Província do seu nascimento, mas não é só o sentimentalismo que lhe guia os passos na peregrinação: é a sina do futuro historiador que investiga os cartórios, compulsa as bibliotecas dos mosteiros, examina os padrões das outras eras, colhe glossários e tradições, e nas localidades comenta e verifica os dizeres de Taques e Frei Gaspar da Madre de Deus.

Voltando a Portugal, nomeado adido à nossa legação, não arrefece um só instante. Na Revista do instituto pululam as memórias que envia, como os documentos que oferece, e quase não há sessão em que seu nome não apareça. De frente com essas ocupações, que satisfariam outros menos ambiciosos, ou fatigariam outros menos diligentes, leva os encargos de editor: reimprime o Caramurú e o Uruguai, e publica a até então desconhecida Narrativa de Fernão Cardim, o provincial jovial, bonachão e viveur, tão familiar aos leitores das Minas de prata de José de Alencar. 
Aos tempos que passou em Lisboa ou aos que de perto se seguem, prendem-se duas obras importantes: O florilégio da poesia brasileira, com um esboço de história literária, onde têm ido beber - muitas vezes sem confessá-lo - todos os que se têm ocupado com o assunto, e a edição do Roteiro do Brasil, de Gabriel Soares, um dos seus maiores e melhores títulos à gratidão do porvir.

Em Madri, para onde mais tarde foi removido, possui-o o mesmo espírito febril, e a ideia, que se tornara fixa, da história pátria. Em Simancas, como em Sevilha, na Biblioteca Columbiana, como na do Escorial, colige a messe opulenta que ninguém ainda teve tão completa, e, quando enfim saiu à luz a sua História, podia gabar-se de que um só fato não existia que não tivesse pessoalmente examinado, ao passo que os fatos materiais por ele descobertos, ou retificados, igualavam, se não excediam, aos que todos os seus predecessores tinham aduzido.

Esgotada a primeira edição da História, com uma rapidez de que entre nós há poucos exemplos, não se dá pressa em reimprimi-la; enfeixa novos dados, visita as províncias; explora todos os lugares históricos, sobe o rio da Prata, tendo à mão o roteiro de Pero Lopes; imprime ou reimprime manuscritos raros ou curiosos.

Do Paraguai traz as obras de Montoya, hoje tão accessíveis e úteis graças a ele e a Platzmann. No Chile discute os diários de Colombo e procura fixar a posição da verdadeira Guanahani. No Peru, em Venezuela, em Cuba, como em São Petersburgo, Estocolmo e Rio de Janeiro, em todos os lugares que habita, ou atravessa, levado pelos deveres de diplomata ou capricho de touriste, principalmente em Viena, onde ultimamente residia deixa traços fulgurantes de sua passagem em páginas inspiradas pelo amor do futuro da Pátria e dominados pela preocupação constante de seu passado.

Se a história do Brasil ocupa as suas faculdades, não as ocupa exclusivamente: aqui publica o Livro das trovas e cantares, o Cancioneiro do Conde de Barcelos, o Cancioneiro da Vaticana, que tanto concorreram para o conhecimento da poesia portuguesa antiga. Ali edita as obras de Vespúcio, escreve-lhe a biografia, comenta-o, defende-o, sustenta os seus direitos à descoberta do continente que guarda seu nome. Além vulgariza a obra de Garcia da Orta, rara tanto como preciosa, ou a carta de Colombo, escrita ao voltar da primeira viagem. Hoje bate-se com D’Avezac, Major e Netscher; mais tarde disserta sobre as novelas e livros de cavalaria portuguesa, e afirma a origem turânia dos povos americanos. Por fim entrega-se aos trabalhos de pura fantasia: na Lenda de Sumé celebra a tradição encontrada pelos primeiros exploradores de um homem que ensinara aos indígenas a agricultura e os rudimentos de civilização que 
possuíam; no drama de Amador Bueno mostra-nos a literatura nacional como a compreende, e introduz-nos na sociedade dos tempos coloniais.

Sempre e sempre perseguia-o a ideia da história pátria. Enquanto não publicava a nova edição, ou antes a refusão e remodelo da obra, escreveu um dos mais nobres capítulos, a História das lutas holandesas, em cuja confecção empregou documentos abundantíssimos, descobertos nos exames a que procedeu nos arquivos de Amsterdã e Haia.

Depois de constantes revisões que lhe levaram mais de vinte anos, publicou de novo a História geral do Brasil, e, para tornar o preço menos elevado, cede ao editor a propriedade da edição sem retribuição alguma. Como coroa de seus cabelos brancos, sonha uma terceira edição para que desde então começou a preparar-se, e prometeu-nos a História da Independência, infelizmente destinada talvez a não ver a luz. ${ }^{86}$ Em seguida abandona a posição cômoda e brilhante de nosso ministro em Viena, para, nos confins de nossos sertões, procurar um lugar pela posição defensável, pela situação central, pelas condições higiênicas, próprio a servir de capital a esta pátria, que tanto amava e que não mais devia ver. Enquanto demorou nesta cidade examinou os panfletos, jornais e memórias contemporâneos do primeiro reinado que ia agora historiar; publica na Revista do instituto o texto mais completo e fiel que possuímos da carta encantadora de Vaz de Caminha. De passagem por Porto Seguro, reconhece as localidades que viu Cabral na sua viagem afortunada. Apenas chega a Viena, envia-nos o folheto retificando um erro que deixara escapar quando confundiu em um dois botânicos brasileiros.

Pouco antes de morrer, quando a enfermidade mortal o obrigava a guardar o leito, escrevendo a um amigo, o Dr. Ramiz Galvão, muito digno diretor da Biblioteca Nacional, quase nem alude às dores que o conservam prostrado e impotente: sobre questões de história pátria, sobre pontos obscuros que deseja esclarecidos, sobre manuscritos, cuja existência deseja conhecer, é que rola toda a carta.

Nobre e tocante vida votada ao trabalho e ao dever! Grande exemplo a seguir e a venerar!

Descoberto este continente, aqueles mesmos que tinham chamado a Colombo visionário foram os primeiros a achar facílima a empresa e a gabar-se de poder executá-la. Depois que Varnhagen publicou sua

86 A História da Independência acabou publicada postumamente, na Revista do IHGB, Tomo LXXIX, 1916. 
História, e apresentou a massa ciclópica de materiais que acumulara, muitos se julgaram aptos a erguer um monumento mais considerável, e atiraram-lhe censuras e diatribes que profundamente nos pungiram. Também ele tinha muitos pontos vulneráveis. Era dos homens inteiriços, que não apoiam sem quebrar, não tocam sem ferir, e matam moscas a pedradas, como o urso do fabulista. Em muitos pontos em que sua opinião não era necessária, ele a expunha complacentemente, com tanto maior complacência quanto mais se afastava da opinião comum. Suas reflexões às vezes provocam um movimento de impaciência que obriga a voltar a página ou a fechar o volume. Muitos assuntos sem importância, ou de importância secundária, só o ocupam por serem descobertas suas. A polêmica com João Lisboa, em que tinha talvez razão, porém em que teve a habilidade de por todo o odioso de seu lado, converteu em inimigos seus os numerosos admiradores do grande maranhense. Homem de estudo e meditação, desconhecia ou desdenhava muitas das tiranias que se impõem com o nome de conveniências. Sensível ao vitupério como ao louvor, se respirava com delícias a atmosfera em que este lhe era queimado, retribuía aquele com expressões nada menos que moderadas.

Essas feições são as que geralmente se associam no espírito do leitor brasileiro ao nome do Visconde de Porto Seguro. Ninguém procura sob as aparências rudes o homem verdadeiro - o trabalhador possante, o explorador infatigável, o mergulhador que muitas vezes surgia exausto e ensanguentado, trazendo nas mãos pérolas e corais. Parece que nos domina a fatalidade de perceber os objetos sob os aspectos mais desfavoráveis; uma idiossincrasia tinge tudo de negro ou amarelo: cedemos a uma predisposição pessimista, niilista, anárquica, talvez bebida com as águas, ou inspirada com as nossas brisas, talvez herdada dos Tupis que, segregados por lutas intestinas e rivalidades perpetuamente renascentes, não conseguiram fundar um estabelecimento análogo ao que se encontrou no México e no Peru.

Entretanto, é difícil exagerar os serviços prestados pelo Visconde de Porto Seguro à história nacional, assim como os esforços que fez para elevar-lhe o tipo. Não se limitou a dar o rol dos reis, governadores, capitães-móres e generais; a lista das batalhas, a crônica das questiúnculas e intrigas que referviam no período colonial. Atendeu sem dúvida a estes aspectos, a uns porque dão meio útil e empírico de grupar os acontecimentos, a outros, porque rememoram datas que são doces ao orgulho nacional, ou melhor esclarecem as molas que atuam sob diferentes ações. Fez mais. As explorações do território, a cruzada cruenta contra os Tupis, o aumento da população, os começos da indústria, as 
descobertas das minas, as obras e associações literárias, as comunicações com outras nações, assumem lugar importante em sua obra.

A sua opinião sobre os Tupis tem encontrado geral desfavor: julga que a compressão exercida sobre eles era mais que necessária, era indispensável, e aos seus olhos as bandeiras que os paulistas levaram até as missões jesuíticas eram a solução mais natural que se podia imaginar. Sem querer defendê-lo, pode-se em todo caso chamar a atenção para circunstâncias atenuantes. Ele não colocou o debate no terreno abstrato e absoluto da justiça, porém no da conveniência e da utilidade. Na tragédia que se desenrolava nas veigas platinas, ou nos campos amazônicos, não via a braços a liberdade e a escravidão, porém, jesuítas que queriam isolar os caboclos para convertê-los em instrumento de manejos políticos, e patriotas que queriam incorporá-los à civilização transformada em forças vivas do progresso. Quem comparar o estado de São Paulo com a calma podre daquele cemitério de um povo que se chama Paraguai; quem não esquecer que nesses dois lugares funcionaram o sistema que ele defende e o que combate, hesitará certamente antes de condenar o historiador. Além disso, o exagero a que depois levou uma ideia justificável, se não justa, a princípio não existia: brotou de contradições veementes e polêmicas irritantes. Acresce enfim que espírito introspectante, natureza subjetiva, determinada antes por impulsos íntimos que influências extrínsecas, Varnhagen não primava pelo espírito compreensivo e simpático, que, imbuindo o historiador dos sentimentos e situações que atravessa - o torna contemporâneo e confidente dos homens e acontecimentos.

A falta de espírito plástico e simpático - eis o maior defeito do Visconde de Porto Seguro. A História do Brasil não se lhe afigurava um todo solidário e coerente. Os pródromos da nossa emancipação política, os ensaios de afirmação nacional que por vezes percorriam as fibras populares, encontram-no severo e até prevenido. Para ele, - a Conjuração Mineira é uma cabeçada e um conluio; a Conjuração Baiana de João de Deus, um cataclisma de que rende graças à Providência por nos ter livrado; a Revolução Pernambucana de 1817, uma grande calamidade, um crime em que só tomaram parte homens de inteligência estreita, ou de caráter pouco elevado. Sem D. Pedro a independência seria ilegal, ilegítima, subversiva, digna da forca ou do fuzil. Juiz de Tiradentes e Gonzaga, ele não teria hesitado em assinar a mesma sentença que o desembargador Diniz e seus colegas.

Mesmo assim a obra de Varnhagen se impõe ao nosso respeito e exige a nossa gratidão, e mostra um grande progresso na maneira de conceber a história pátria. Já não é a concepção de Gândavo e Gabriel 
Soares, em que o Brasil é considerado simples apêndice de Portugal, e a história um meio de chamar a emigração, e pedir a atenção do governo para o estado pouco defensável do país, sujeito a insultos de inimigos, contra os quais se reclama proteção. Não é a concepção dos cronistas ecclesiásticos, que vêem simplesmente uma província, onde a respectiva Congregação prestou serviços, que procuram realçar. Não é a de Rocha Pita, atormentado pelo prurido de fazer estilo, imitar Tito Lívio e achar no solo americano cenas que relembrem as que passaram na Europa. Não é a de Southey, atormentado ao contrário pela impaciência de fugir às sociedades do Velho Mundo, visitar países pouco conhecidos, saciar a sede de aspectos originais e perspectivas pitorescas, a que cedem todos os poetas transatlânticos, desde os autores de Atala e do Corsário até os das Orientaes e Clara Gazul... Não. Varnhagen atende somente ao Brasil, e no correr de sua obra procurou sempre, e muitas vezes conseguiu colocar-se sob o verdadeiro ponto de vista nacional.

É pena que ignorasse ou desdenhasse o corpo de doutrinas criadoras que nos últimos anos se constituíram em ciência sob o nome de sociologia. Sem esse facho luminoso, ele não podia ver o modo por que se elabora a vida social. Sem ele as relações que ligam os momentos sucessivos da vida de um povo não podiam desenhar-se em seu espírito de modo a esclarecer as diferentes feições e fatores reciprocamente. Ele poderia escavar documentos, demonstrar-lhes a autenticidade, solver enigmas, desvendar mistérios, nada deixar que fazer a seus sucessores no terreno dos fatos: compreender, porém, tais fatos em suas origens, em sua ligação com fatos mais amplos e radicais de que dimanam; generalizar as acções e formular-lhes teoria; representá-las como consequências e demonstração de duas ou três leis basilares, não conseguiu, nem consegui-lo-ia.

Fa-lo-á alguém? Esperemos que sim. Esperemos que alguém, iniciado no movimento do pensar contemporâneo, conhecedor dos métodos novos e dos instrumentos poderosos que a ciência põe à disposição de seus adeptos, eleve o edifício, cujos elementos reuniu o Visconde de Porto Seguro.

Sinais de renascimento nos estudos históricos já se podem perceber. Publicações periódicas vulgarizam velhos escritos curiosos, ou memórias interessantes esclarecem pontos obscuros. Muitas províncias compõem as respectivas histórias. Períodos particulares, como a Revolução de 1817, a Conjuração Mineira, a Independência, o Primeiro Reinado, a Regência, são tratados em interessantes monografias. Por toda parte pululam materiais e operários; não tardará talvez o arquiteto. 
Que venha, e escreva uma história da nossa pátria digna do século de Comte e Herbert Spencer. Inspirado pela teoria da evolução, mostre a unidade que ata os três séculos que vivemos. Guiado pela lei do consensus, mostre-nos o rationale de nossa civilização, aponte-nos a interdependência orgânica dos fenômenos, e esclareça uns pelos outros. Arranque das entranhas do passado o segredo angustioso do presente, e liberte-nos do empirismo crasso em que tripudiamos. Mas, ah! bem pouco digno serás de tua missão, oh! nobre pensador, se não sentires a gratidão inundar-te o peito, se não sentires o respeito e a veneração dominarem-te a alma, se não ajoelhares fervoroso e recolhido ante o túmulo de um grande combatente, que jamais abandonou o campo - Francisco Adolfo de Varnhagen, Visconde de Porto Seguro.

João Capistrano de Abreu (1878) 


\section{O pensamento histórico no Brasil nos últimos cinquenta anos ${ }^{87}$}

Não é fácil distinguir a situação do pensamento histórico no Brasil durante este meio século sem fixar o papel eminente de quem deu o primeiro passo para ampliar decisivamente suas perspectivas. Na obra de Capistrano de Abreu, é certo que a erudição teria de predominar de modo absorvente sobre a especulação, e só por vias indiretas é possível determinar razoavelmente o que fosse o "pensamento" histórico nela representado.

Entretanto, em nítido contraste com tantos dos seus predecessores, e refiro-me neste caso aos mais ilustres, o fato bruto e o simples testemunho documental não imperam esmagadoramente nessa obra. Nem, e muito menos, constituem aquela argila maleável de que fazem construções imaginosas, próprias para lisonjear interesses, vaidades ou paixões da hora que passa.

Desses riscos extremos, a que sucumbem, talvez, em sua maioria, os estudiosos de nosso passado, achou-se admiravelmente preservada a obra de Capistrano de Abreu. Pesquisador constante e nunca inteiramente satisfeito, tendo trabalhado mais do que qualquer outro depois de Varnhagen, para revelar, valorizar e bem aproveitar testemunhos escritos de nossa formação nacional, ele sabia, no entanto, que esses documentos só falam verdadeiramente aos que ousam formular-lhes perguntas precisas e bem pensadas. Sabia, em outras palavras, palavras de um grande mestre moderno - Marc Bloch -, que toda pesquisa histórica supõe, desde os passos iniciais, que o inquérito tenha uma direção definida. No princípio está o espírito. Nunca, em ciência alguma, a observação simplesmente passiva conduziu a resultados fecundos.

Qual o espírito, porém, qual o pensamento informador dessa obra que deveria marcar o ponto de partida para um novo rumo nos estudos históricos entre nós? Sabemos que em sua mocidade o autor não fora infenso ao positivismo comtiano e que mais tarde aderira com mais firmeza e fervor às doutrinas de Spencer. Mas dos princípios positivistas e evolucionistas só guardaria obstinadamente o senso da medida, da precisão, do rigor nos raciocínios, que retém a imaginação dentro de limites

87 Publicado originalmente no Correio da Manhã do Rio de Janeiro, em 15 de julho de 1951. Reproduzimos aqui o texto contido em EUGÊNIO, João Kennedy; MONTEIRO, Pedro Meira. Sérgio Buarque de Holanda: perspectivas. Campinas, SP: Editora da Unicamp; Rio de Janeiro, RJ: EdUERJ, 2008, p. 601-615. Agradecemos a Pedro Meira Monteiro, e Paulo Franchetti (da Editora da Unicamp), consultados quanto à questão da liberação do texto para reprodução, e aos filhos de Sérgio Buarque de Holanda, Sergito, Álvaro, Heloísa, Ana, Francisco, Maria do Carmo e Maria Christina, que gentilmente permitiram sua publicação. 
plausíveis, além de uma sensibilidade aguçada à importância de ação dos fatores cósmicos - da terra, do meio e do clima - sobre as instituições humanas.

Em seus escritos, bem raras são as referências a historiadores contemporâneos. Em compensação, divulgou e traduziu alguns geógrafos (e antropólogos), não só aqueles que, como Wappäus e Sellin, se ocuparam expressamente do Brasil, mas ainda os que, como Kirchhoff, encaram de maneira geral as relações recíprocas entre o homem e a terra. O valor atribuído à paisagem natural na formação e evolução dos agrupamentos humanos bem se reflete nas palavras em que, comentando um dos capítulos do livro de Sellin, escreve que nela o lado geográfico deveria predominar com maior vigor.

Há, em sua caracterização desse livro, todo um programa de trabalho que, dentro dos limites cronológicos previstos, iria desenvolver finalmente em sua pequena obra mestra - os Capítulos da história colonial -, publicada pela primeira vez em 1907; programa que diverge fundamentalmente de todas as tentativas anteriores do mesmo tipo. Aqui, os aspectos mais nitidamente políticos e os que dependem da pura ação individual, dificilmente redutíveis a qualquer determinismo, cedem passo a outros, aparentemente humildes e rasteiros, que mal encontravam guarida na concepção tradicional da história.

Assim é que às guerras flamengas, por exemplo, um dos temas diletos de antigos historiadores, consagra apenas trinta e poucas páginas, contra mais de cem devotadas ao povoamento do sertão; quase o inverso da proporção relativa que têm essas matérias na primeira edição da História geral de Varnhagen. E no povoamento do sertão distingue expressamente entre as expedições colonizadoras, que alcançariam influência perdurável, e outras, que lhe parecem apenas despovoadoras e devastadoras: só as primeiras o interessam vivamente. Na história do extremo sul, volta-se com antipatia manifesta contra as fases bélicas, revolucionárias, "heroicas". À própria Inconfidência, movimento político explicável pela influência de ideias adventícias - que não se entranham em nossa tradição vinda dos primeiros tempos da colónia -, reage por um silêncio sintomático e certamente deliberado.

As consequências naturais dessa atitude não se fizeram imediatamente sentir em toda a sua extensão, mesmo no círculo dos seus discípulos e companheiros diletos. Na obra de Calógeras, por exemplo, que nos deu em Formação histórica do Brasil como um prolongamento dos Capítulos, só as primeiras seções, inspiradas diretamente na obra de Capistrano, refletem um pouco do mesmo espírito. No mais, vamos encontrar apenas o investigador paciente e seguramente informado que, 
em Política exterior do Império, atentara principalmente para questões políticas e diplomáticas. Seria injusto negar, entretanto, que em seu longo estudo acerca das Minas do Brasil e sua legislação (impresso entre 1904 e 1905) e, sobretudo, na breve e admirável síntese contida em sua conferência de 1912, na Biblioteca Nacional (O Brasil e seu desenvolvimento econômico), Calógeras mostrou as amplas perspectivas que oferece a exploração de um domínio quase virgem: o de nossa história econômica.

Mais fecundo foi o exemplo de Capistrano e também o do Barão do Rio Branco nos terrenos da investigação e informação erudita. As anotações do primeiro à Guerra da Tríplice Aliança de Schneider e os notáveis "Prolegômenos" do segundo à História de Frei Vicente do Salvador permanecem modelos de trabalho que tiveram seguidores eméritos, como Rodolto Garcia - que comentou a maior parte da História geral do Visconde de Porto Seguro (o primeiro volume já fora anotado pelo próprio Capistrano), além de crônicas coloniais, como os tratados de Fernão Cardim, os Diálogos das grandezas do Brasil e a Viagem de Claude d'Abbeville - e também Eugênio de Castro, organizador e anotador da edição do Diário de navegação de Pero Lopes de Souza, publicada em 1928 e reimpressa em 1940, por ocasião dos centenários portugueses.

Onde, porém, a ênfase maior dada a certos aspectos da história geográfica e social se revelou em toda a sua importância foi na divulgação de documentos capazes de abrir novo sulco para estudos de história social ou econômica e não apenas política, bélica e genealógica. O impulso mais decisivo nesse sentido foi a impressão, por iniciativa de Washington Luiz - ele próprio historiador e atento ao valor das fontes manuscritas -, das séries de Atas da Câmara de Santo André (1914) e de São Paulo, iniciadas, estas em 1914, e ainda hoje em curso de publicação, assim como a do Registro geral da Câmara de São Paulo (iniciada em 1917), dos Inventários e testamentos (iniciada em 1920) e das Sesmarias (iniciada em 1921).

À impressão desses valiosos documentários deve-se o surto de estudos sobre o passado paulista, especialmente sobre a expansão geográfica do Brasil colonial. Sem os Inventários e testamentos não teria sido possível um trabalho como o de Alcântara Machado sobre a Vida e morte do bandeirante, publicado em 1930. E sem os textos municipais mal se conceberiam os valiosos estudos de Afonso d'E. Taunay sobre São Paulo no século XVI, prolongados depois em sua história da vila e da cidade de São Paulo. O acesso mais fácil a esses documentos permitiu, além disso, os numerosos trabalhos de reconstituição e revisão da história paulista e das bandeiras, empreendidos por Washington Luiz, Basílio de Magalhães, Paulo Prado, Ellis Júnior, Américo de Moura, Carvalho Franco, 
Cassiano Ricardo, Aureliano Leite, Nuto Sant'Ana e muito especialmente Afonso d'E. Taunay, cuja opulenta História geral das bandeiras paulistas começou a publicar-se em 1924 e só se completou neste ano de 1951, abrangendo ao todo onze copiosos volumes.

A elaboração metódica da história das bandeiras paulistas pode dizer-se que só se tornou realidade neste meio século, e isso graças especialmente aos textos exumados dos arquivos paulistas e ainda a publicações estrangeiras, como a dos documentos sobre o Paraguai jesuítico impressos na Espanha pelo padre Pablo Pastells e os manuscritos do arquivo de Sevilha divulgados, por iniciativa de Taunay, em vários tomos dos Anais do Museu Paulista. O movimento promete prosseguir nos próximos anos com os trabalhos recentes do historiador português Jaime Cortesão e sobretudo com o preparo, a seu cargo, de numeroso material manuscrito da Coleção de Angelis, cuja publicação há de ser brevemente iniciada pela Biblioteca Nacional.

Outro problema de nossa história colonial que pôde ser explorado e amplamente iluminado nestes cinquenta anos foi o das atividades da Companhia de Jesus nos primeiros séculos da colonização. O renascimento dos estudos jesuíticos pode dizer-se que data do $3^{\circ}$ centenário da morte de Anchieta. O volume impresso justamente em 1900, onde se reúnem as conferências - entre outros, de Eduardo Prado, Joaquim Nabuco, Teodoro Sampaio, Couto de Magalhães e Brasílio Machado - pronunciadas por motivo de celebração, é sem dúvida uma contribuição apreciável. Não dispondo, contudo, de novas peças documentárias, os autores pouco acrescentaram, do ponto de vista informativo, ao que já se sabia da atividade colonial dos inacianos. Dessa carência de documentação ressentem-se ainda algumas obras posteriores, como a do padre Luís Gonzaga Cabral, ou mesmo o extenso trabalho sobre a liberdade dos índios e a Companhia de Jesus, que J. M. Madureira apresentou em Congresso Internacional de História da América e se publicou em 1929.

É certo que a bibliografia relacionada com os jesuítas no Brasil não deixara de enriquecer-se no intervalo que separa essa publicação das comemorações do tricentenário de Anchieta. Em sua maioria, porém, o documentário divulgado não se referia propriamente à província do Brasil. É o caso, por exemplo, da já citada compilação do padre Pastells e das numerosas peças abrangidas no terceiro volume, de 1922, da História do Rio Grande do Sul, do padre Carlos Teschauer. Todos esses papéis referem-se naturalmente ao extremo sul do Brasil. Sobre o extremo norte existia, desde 1901, o importante trabalho do historiador português João Lúcio de Azevedo consagrado aos Jesuitas do Grão-Pará. Ao mesmo historiador devemos uma história do padre Vieira, impressa pela primeira 
vez em 1918, e também uma edição nova e enriquecida das cartas de Vieira, que vieram enriquecer consideravelmente nosso conhecimento da vida e obra do grande pregador.

Nos anos seguintes, a reunião das demais cartas jesuíticas - já conhecidas - sobre o Brasil, em volumes copiosamente anotados, iniciativa da Academia de Letras, pôde reavivar o interesse pelo estudo da participação dos padres da Companhia na colonização. O passo mais importante para a revelação ampla da obra da Companhia no Brasil seria dado a partir do mesmo decênio de 30 pelo padre Serafim Leite. Seus estudos e conferências reunidos em 1937 nas Páginas de história do Brasil constituíam apenas uma amostra, ampliada em $1940 \mathrm{com}$ as Novas cartas jesuíticas, da riqueza de peças documentais que o autor pudera coligir não só no Arquivo da Sociedade de Jesus em Roma, como ainda em outros arquivos europeus. O principal resultado dessas pesquisas seria a História da Companhia de Jesus no Brasil que principiou a publicar-se em 1938 e de que em 1950 saiu o décimo e último volume. Não se poderia esperar melhor remate para o meio século de investigações de inúmeros historiadores em torno da obra de catequese e colonização empreendida pela milícia de Santo Inácio.

Outro aspecto da história do Brasil que pode esclarecer-se largamente neste meio século é o relativo às questões com o Prata durante o Império. Sobre a Guerra do Paraguai especialmente, os longos estudos de Tasso Fragoso (1934) e Ramón Cárcano (1939-42), escritos um do ponto de vista brasileiro e outro do argentino, fornecem elementos numerosos para a boa compreensão dos diferentes episódios da campanha da Tríplice Aliança. Outros elementos puderam ser propiciados com a impressão, em 1925, dos diários do exército em operações sob o comando de Caxias; em 1936, do diário de viagem do Conde d'Eu; e, em 1910, das reminiscências de Dionísio Cerqueira. A publicação, em diversos volumes, de trabalhos esparsos do Visconde de Taunay, incluindo material inteiramente inédito até 1924, data da edição, tornou acessíveis algumas das contribuições fundamentais do autor da Retirada da Laguna.

Em muitas obras existentes sobre o assunto, a parte polêmica ainda é considerável e às vezes dominante. Uma das mais recentes, a do embaixador Cárcano, que pretende assumir posição de perfeita imparcialidade, encerra numerosas teses que não receberam aquiescência tranquila no Brasil ou na própria Argentina. O ponto de vista brasileiro a respeito de algumas dessas teses foi ultimamente defendido pelo sr. Júlio de Mesquita Filho, em um dos seus Ensaios sul-americanos.

Divergências semelhantes subsistem, como seria de esperar, a propósito das campanhas platinas do Primeiro Reinado. Um dos 
episódios dessas lutas deu motivo ao trabalho do embaixador José Carlos de Macedo Soares sobre os Falsos troféus de Ituzaingó e, posteriormente, ao de Tasso Fragoso, onde estuda a Batalha do Passo do Rosário. Sobre os acontecimentos que se seguiram às campanhas da Cisplatina e precederam à guerra da Tríplice Aliança, há material farto e documentado nos livros de Souza Docca (1919) e de Pelham Horton Box (1927), este último em inglês e dedicado expressamente aos antecedentes do conflito. Hélio Lobo publicou, em Às portas da guerra (1916), os resultados de suas pesquisas em arquivos diplomáticos sobre os fatos que precederam imediatamente às hostilidades. Em $A$ invasão paraguaia no Brasil, Walter Spalding apresentou-nos, em 1940, material ainda em grande parte desconhecido acerca do desenvolvimento da guerra. E nestas últimas semanas, com a publicação do precioso $C a$ tálogo da Coleção Rio Branco, abrangendo 5122 entradas, e cujo fundo é constituído de peças dos arquivos paraguaios, o nosso Ministério das Relações Exteriores veio oferecer um manancial opulento aos estudiosos desse aspecto de nossa história militar.

Não se pode finalmente esquecer, entre os progressos realizados neste meio século para o melhor conhecimento de nosso passado, a divulgação extensa de textos mais exatos e completos referentes à fase inicial da ocupação do solo. A publicação, em Portugal, dos três volumes da monumental História da colonização portuguesa - comemorativa do primeiro centenário da Independência e abrangendo textos numerosos transcritos geralmente com zelo e precedidos de comentários eruditos - representou, por esse lado, uma iniciativa memorável. E que teve logo quem, seguindo seu exemplo, tratasse de dotar-nos de documentário mais idôneo e lucidamente interpretado. Basta lembrar, a esse respeito, a já citada publicação do Diário de Pero Lopes, comentada por Eugênio de Castro; o novo texto português, exaustivamente anotado da Nova gazeta de 1514, que organizou Clemente Brandenburger, e ainda a excelente edição e os valiosos comentários da carta de Pero Vaz de Caminha, que devemos a Jaime Cortesão. No mesmo espírito, e já em 1922, publicara em Nova Iorque, The Cortes Society, o texto fac-símile da História de Gândavo, enriquecido de importantes notas e comentários de John B. Stetson Jr.

Com algumas reservas, talvez, na parte que se relaciona às campanhas sulinas do Império, o interesse por todos esses diferentes problemas que, através deste meio século, puderam ser melhor esclarecidos - descobrimento e ocupação da terra, atividade dos jesuítas e conquista do sertão -, deveu muita coisa, sem dúvida, à ação estimulante de Capistrano de Abreu. Especialmente no que diz respeito à atividade da 
Companhia de Jesus, é bem conhecida sua opinião de que seria presunçoso quem escrevesse a história do Brasil sem antes se escrever a dos jesuítas. Se isso fosse verdadeiro, caberia dizer que, já agora, é lícito escrever a história do Brasil sem presunção.

Independentemente desse estímulo, não faltaram, é certo, as tentativas muitas vezes laboriosas, mas fundadas num critério de apresentação sobretudo cumulativa dos fatos históricos, como ocorre na considerável História do Brasil de Rocha Pombo. Entretanto, um esforço isolado que significou importante contribuição metódica para o estudo de nosso passado é o volume extremamente condensado que João Ribeiro destinou a fins didáticos. Pela sua estrutura e pelo sistema de exposição adotado, afasta-se esta obra das tendências mais generalizadas entre seus contemporâneos e antecessores brasileiros. Ao menos na sua característica divisão do país em regiões históricas bem definidas, parece filiar-se melhor ao programa contido nas Ideias gerais de Martius, impressas em 1845, e ainda à História do Brasil de H. Handelmann, que, publicada em alemão há mais de um século, só teria tradução portuguesa em 1931.

A existência de núcleos de estudiosos, congregados, em sua generalidade, à volta de instituições provinciais criadas nos moldes do Instituto Histórico e Geográfico Brasileiro, tornou possível, em certos casos, o desenvolvimento acentuado de estudos regionais já em princípios deste século. A orientação do Barão de Studart, por exemplo, que até a sua morte, em 1927, esteve à frente do Instituto do Ceará, muito contribuiu certamente para o desenvolvimento de aturadas pesquisas sobre o povoamento do litoral e do sertão do Nordeste. Igualmente importante foi a atuação de um José Higino, de um Alfredo de Carvalho, de um Pereira da Costa, de um Rodolfo Garcia, em Pernambuco. Ou, na Bahia, de um Borges de Barros, de um Braz do Amaral, de um Teodoro Sampaio, de Orville Derby, de Toledo Piza, de Eduardo Prado. Publicações como a revista do Arquivo Público Mineiro ou a do Instituto Histórico do Rio Grande do Sul, entre outras, ampliaram, por vezes desordenadamente, o mesmo esforço sobre outras áreas.

Se, numa caracterização feita a traço grosso, é possível dizer que a obra de Capistrano de Abreu acentuou o papel de determinismo, sobretudo de determinismo geográfico (e também de certos aspectos antropológicos, mormente os que se relacionam à influência indígena) na vida brasileira, não faltaram, neste meio século, os que fizeram recair o acento tônico sobre certas fases do nosso passado, encaradas através da atividade de um indivíduo. A obra exemplar no gênero - Um estadista do Império, de Joaquim Nabuco -, publicada em 1889, oferece-nos um 
opulento painel do Segundo Reinado, onde o calor e a devoção filial não chegam a perturbar a visão nítida do historiador.

Escrita necessariamente com outro espírito, e principalmente com as vantagens - e as desvantagens - da maior distância no tempo, a principal obra de Oliveira Lima - o D. João VI no Brasil -, publicada em 1908, continua sendo a mais ampla fonte de informações acerca do Brasil Reino. A publicação do volume de Tobias Monteiro sobre a Elaboração da Independência, em que sobressaem os aspectos íntimos e anedóticos da vida brasileira ao tempo do rei, não conseguiu relegá-lo a segundo plano.

Entre outras obras de fundo biográfico que representam considerável contribuição para o conhecimento do passado brasileiro, caberia ainda lugar de destaque à série de escritos sobre a vida e obra de Mauá, que devemos a Alberto Faria, Castro Rebelo, Lídia Besouchet e Cláudio Ganns. Estudos mais recentes, como os de Heitor Lira sobre Pedro II, Wanderley Pinho sobre Cotegipe - de que só se publicou o primeiro volume -, de Alberto Rangel sobre D. Pedro I e a Marquesa de Santos, de Marcos de Mendonça sobre o Intendente Câmara, de Álvaro Lins sobre o Barão do Rio Branco, servem para demonstrar a fertilidade de um gênero que a forma espúria e menos recomendável constituída pelas modernas biografias romanceadas não conseguiu desmoralizar. Entre as obras biográficas que representam contribuição insubstituível para a inteligência histórica, é preciso assinalar particularmente a série de obras com que o sr. Otávio Tarquínio de Souza vem alargando nosso conhecimento da fase da Regência - enquanto não aborda mais amplamente a do Primeiro Reinado -, através de estudos em torno de algumas de suas figuras centrais: Evaristo da Veiga, Bernardo de Vasconcelos, Feijó e José Bonifácio.

Ao lado dos estudos estritamente históricos - e sem falar nos de história artística e literária, que não cabem nesta resenha -, devem mencionar-se, ao menos de passagem, algumas obras que, situadas embora na periferia desses estudos, vieram enriquecê-los de modo apreciável. Refiro-me em particular aos ensaios de investigação e interpretação social que passaram aos poucos a empolgar numerosos espíritos. Trabalhos parciais de Couto de Magalhães, Batista Caetano, Macedo Soares, Rebouças, Sílvio Romero, José Veríssimo, Teodoro Sampaio, Orville Derby, Euclides da Cunha, Nina Rodrigues, Manuel Bonfim, Alberto Torres, entre outros, abriram sendas para um tipo de pesquisa que nossos historiadores mal tinham praticado.

O primeiro estudo sociológico de Oliveira Vianna - as Populações meridionais do Brasil - é também obra de historiador. Em seu inquérito sobre as populações do centro-sul do país, ele procurou aplicar primeiramente os métodos elaborados em parte por Le Play, à medida que se 
adaptavam à observação indireta. Em trabalhos posteriores, ampliou-o com o recurso a doutrinas que davam predominância aos elementos raciais. Ao determinismo geográfico, afugentado de certo modo nos trabalhos iniciais, substituía-se agora uma espécie de determinismo biológico. Simultaneamente, o autor dedicou-se a ensaios de história social e psicológica inspirados por fatos e personalidades do Império, sobretudo do Segundo Reinado, dando certa popularidade a um gênero de ensaios interpretativos já realizado com bom êxito por Euclides da Cunha, principalmente em Contrastes e confrontos e A margem da história.

Novo e generoso impulso aos estudos interpretativos, com base em amplo material histórico, deu-o o sr. Gilberto Freyre, a partir de 1933, com a publicação de Casa-grande \& senzala. Um conhecimento extenso do passado rural, sobretudo de seu Nordeste, orientado pelo estímulo que lhe forneceram os métodos difusionistas desenvolvidos por Franz Boas e seus discípulos norte-americanos, e por numerosos estudos norte-americanos e europeus sobre contatos sociais e miscigenação, abriulhe perspectivas ideais para abordar nossa formação histórica. Para isso, tomou como ponto de partida o triângulo representado pela família patriarcal, a grande lavoura e o trabalho escravo, analisando suas repercussões sociais em uma série de estudos cujo último volume ainda se encontra em preparo. Embora sem desdenhar, nesses estudos, o fator biológico na constituição da sociedade brasileira, deu maior ênfase - em contraste com Oliveira Vianna - ao elemento cultural, entendido este com o timbre que à palavra "cultura" vêm associando numerosos antropologistas. Cultura compreendida como o conjunto global de crenças, hábitos, ideias, normas de vida, valores, processos técnicos, produtos e artefatos, que o indivíduo adquire na sociedade antes como um legado tradicional do que em resultado de sua própria atividade criadora.

Esse tipo de inquérito levou-o naturalmente a desenvolver, em estudos posteriores, principalmente em Nordeste, o exame das relações entre o homem e a terra nas áreas açucareiras que se alongam pelas regiões litorâneas entre a Bahia e o Maranhão. Associou-lhes a designação de critério ecológico, embora pouco tenham a ver, além do nome, com as teorias de ecologia humana desenvolvidas sobretudo nos Estados Unidos, e particularmente em Chicago, a partir de 1921, por Park e Burgess.

A bibliografia histórica do decênio de 1930 é largamente ocupada por escritos onde a interpretação elucidativa, e às vezes interessada e mesmo deformadora dos fatos, visa a explicar tais fatos ou a caracterizá-los em sua configuração especificamente nacional. A importância de muitos desses escritos, suscitados em parte pelas perplexidades de uma época de crises e transformações, exigiria estudo à parte. E embora 
contribuíssem, muitos deles, para dar novo rumo aos estudos históricos, não seria possível na presente resenha, sem alongá-la em demasia, ir muito além de uma enumeração necessariamente incompleta.

Nesse caso encontra-se, por exemplo, Retrato do Brasil, de Paulo Prado, onde o historiador de Paulística, intimamente vinculado à "escola" de Capistrano de Abreu, se propõe, apoiado em copiosa informação histórica, mostrar que o país ainda dormia "seu sono colonial" e, dois anos antes do movimento de 1930, enuncia a necessidade de se "fazer tábua rasa para depois cuidar da renovação total”. Publicando, já em 1930, a Política geral do Brasil, que além do ensaio interpretativo é uma síntese por vezes sedutora, embora necessariamente parcial, da história do Segundo Reinado e da Primeira República, o sr. José Maria dos Santos adota atitude, de certo modo, oposta. Contra os males do presente, que procura apresentar como fruto de um processo involutivo, nascido da "deformação republicana", acena sem hesitar para remédios do passado. Ao presidencialismo contrapõe as vantagens do parlamentarismo. E a própria Revolução de 1930 não lhe parece que virá interromper, mas antes agravar, os danos do princípio presidencial, pois prepara o advento do caudilhismo e da "era do cavalo".

Em numerosos estudos de "formação", publicados pela mesma época, encontra-se insistente o apelo àquilo que um ensaísta norte-americano denomina o "passado utilizável", para a composição de quadros empolgantes que se apresentam ao mesmo tempo como terapêutica ideal para todas as nossas mazelas. Essas supostas reconstruções, que levadas à sua forma extrema desembocariam em manifestações totalitaristas, especialmente na doutrinação integralista, mal interessam, em sua generalidade, à pesquisa historiográfica.

Mais interessantes, por todos os aspectos, são sem dúvida as tendências de explicações de paisagens regionais, em que um critério por vezes apologético não impede a iluminação de alguns problemas históricos muitas vezes descurados. Em seu livro sobre a Formação do Rio Grande do Sul, que retoma o assunto já abordado em ensaio breve, mas extremamente condensado de Rubem de Barcelos, Jorge Salis Goulart procura caracterizar o passado e presente das populações sulinas com o socorro da história geográfica, da psicologia social, da sociologia... Servindo-se de critérios semelhantes, o sr. Alfredo Ellis Júnior já abordara anteriormente em sucessivos estudos, os problemas da formação paulista. E o sr. Cassiano Ricardo, em Marcha para o oes$t e$, já parte do regional para o nacional, do passado para o presente $\mathrm{e}$ o futuro, tentando um esforço paralelo ao que desenvolvera Gilberto Freyre no Nordeste. 
A interpretação social e psicológica da vida brasileira, tomada em seu conjunto, e independentemente do ângulo regional, forneceu-nos, pela mesma época, outras obras significativas, e entre elas convém destacar a que publicou em 1936 o sr. Afonso Arinos de Melo Franco sob o título de Conceito de civilização brasileira. Nos anos seguintes e mesmo no início do decênio seguinte, perdura o interesse pelos estudos interpretativos. De 1943 é A cultura brasileira, do sr. Fernando de Azevedo, obra extensa, onde o autor, catedrático de sociologia, familiarizado com métodos de pesquisa social - especialmente os que dependem das teorias durkheimianas -, aplica-os em alguns casos ao exame de nossa evolução social, cultural e política. Em Formação da sociedade brasileira, impressa no ano seguinte, o sr. Nelson Werneck Sodré ambiciona ainda, através da inquirição do passado, servir ao presente e "fornecer instrumentos aplicáveis aos caminhos futuros".

Por menos que esses trabalhos devam inscrever-se na literatura historiográfica, tomada a palavra stricto sensu, é forçoso admitir-se que participam de uma tendência que se reflete vivamente em outras obras da mesma época, onde a interpretação pessoal, endereçada a um alvo determinado, cede passo ao puro esforço de elucidação. Na obra já numerosa do sr. Pedro Calmon, onde se incluem trabalhos sobre a expansão baiana e a Casa da Torre, figura, ao lado da grande História do Brasil, também uma História social do Brasil, que em seu terceiro volume já abrange a fase republicana. Esse interesse pelo social - e no caso também pelo econômico - encontra-se ainda nos estudos históricos do sr. Afonso Arinos de Melo Franco, principalmente os que abordam nossa civilização material, a evolução da economia brasileira e a História do Banco do Brasil, interrompida com o primeiro volume.

Na série de estudos do sr. J. F. de Almeida Prado iniciada com Primeiros povoadores do Brasil e que já compreende, por ora, oito volumes, é utilizado um opulento acervo de testemunhos, sobretudo de viajantes estrangeiros, para a exposição e, não raro, a revisão de fatos da história social e econômica do Brasil durante os séculos iniciais da colonização.

Mesmo numa relação bastante incompleta, como a presente, não seria lícito esquecerem-se certos trabalhos dedicados à história regional, como os de Aurélio Porto e Borges Fortes sobre a colonização do extremo sul, do sr. Artur César Ferreira Reis sobre o extremo norte, do sr. Alberto Lamego sobre a região de Campos dos Goitacazes, do sr. Tavares de Lira sobre o Rio Grande do Norte, do sr. Oswaldo Cabral sobre Santa Catarina, do sr. Aluízio de Almeida sobre o sul de São Paulo, do sr. Noronha Santos, Luiz Edmundo, Vivaldo Coaracy e Gastão Cruls sobre o Rio de Janeiro, de Estevão de Mendonça e do sr. Virgílio Correia Filho 
sobre Mato Grosso, do sr. Romário Martins sobre o Paraná, do cônego Raimundo Trindade sobre a arquidiocese de Mariana, de Rego Monteiro sobre a Colônia do Sacramento, dos srs. José Honório Rodrigues e José Antônio Gonsalves de Mello sobre o domínio holandês no Nordeste. Da obra do sr. Gonsalves de Mello, diretamente influenciada por ideias e escritos do sr. Gilberto Freyre, escreve o sociólogo pernambucano que é "a mais completa, mais minuciosa e mais compreensiva que hoje existe em qualquer língua" sobre o tempo dos flamengos.

Ao lado dos estudos de "formação" já abordados, deveria alinhar-se naturalmente o que devotou o sr. Caio Prado Júnior, em 1942, à interpretação e explicação do Brasil dos nossos dias, através de sua evolução histórica, desde as vésperas da Independência. Obra corpulenta e ambiciosa, pois o volume de amplas proporções já publicado quer ser apenas o primeiro de uma série talvez considerável, poderia tomar lugar entre os vastos estudos histórico-sociológicos dos srs. Oliveira Vianna, Gilberto Freyre e Fernando de Azevedo. A inquirição histórica baseia-se aqui num critério interpretativo fornecido pelas doutrinas do materialismo histórico. Fiel, todavia, aos princípios teóricos que assenta, o estudo do sr. Prado Júnior focaliza muito mais diretamente os problemas econômicos, que lhe parecem, em última instância, os decisivos para a elucidação do passado e do presente. E essa ênfase ganha pela economia aponta para uma direção que tendem a tomar, cada vez mais, entre nós, as pesquisas históricas, abrindo-lhes territórios até aqui mal explorados.

O impulso mais poderoso para esse tipo de pesquisa iniciara-se aliás, com a publicação dos dois volumes da História econômica do Brasil de Roberto Simonsen, onde se abrange grande parte do curso dado pelo autor na Escola de Sociologia e Política de São Paulo. Parte apenas, pois inclui unicamente o período colonial. A outra parte, que não chegara a ser redigida, deveria envolver as questões mais embaraçosas das fases imperial e republicana. É inevitável pensar-se, hoje, que a abordagem dessas questões só será realizável através de um trabalho prévio empreendido por diferentes especialistas que se dediquem, cada qual, a determinada época e a determinados problemas, não por meio de outras sínteses onde o particular tende a esfumar-se e a perder-se em proveito de alguma ilusória visão de conjunto.

Alguns aspectos de nossa história econômica e financeira já puderam ser abordados, sem dúvida, através de estudos monográficos quase exaustivos. Neste caso estaria, em primeiro lugar, a monumental História do café no Brasil, do sr. Afonso d'E. Taunay, cujos quatorze volumes, repletos de minuciosas informações, são bem dignos do autor da História geral das bandeiras. Sobre aspectos gerais de nossa história financeira 
e monetária existem desde há muito trabalhos valiosos, a começar pelos de Sebastião Ferreira Soares, ao tempo da monarquia, e em seguida pelos de Amaro Cavalcanti, Pandiá Calógeras, Severino Sombra, até os mais recentes, como o do sr. Dorival Teixeira Vieira. Sobre a história da indústria extrativa na Amazônia há o trabalho moderno do sr. Artur César Ferreira Reis, que mereceria ser ampliado. E em São Paulo a sra. A. P. Canabrava, apoiando-se em recursos da historiografia moderna, tem abordado várias questões relacionadas ao comércio colonial, especialmente ao comércio de contrabando com o Prata, e à lavoura açucareira no norte do Brasil e nas Antilhas.

A complexidade desses assuntos está a requerer cada vez mais a utilização dos métodos que se vêm desenvolvendo em países onde existe longa tradição de estudos históricos especializados. E a preocupação de assimilar alguns desses métodos e aplicá-los a problemas brasileiros já é hoje o aspecto dominante e creio que o mais auspicioso do pensamento histórico entre nós. A esse propósito não se poderá acentuar demasiado a influência que tem cabido nos últimos anos aos mestres estrangeiros contratados para os institutos universitários. Referindo-se à criação, em 1934 e 1935, das nossas primeiras faculdades de filosofia e letras - a de São Paulo e a do Distrito Federal -, o sr. Fernando de Azevedo pôde notar em A cultura brasileira a carência, sensível àquela época, de personalidades realmente eminentes nos vários domínios da especialização intelectual e científica. Impusera-se, para o magistério de todas as disciplinas, o recurso a missões de professores estrangeiros - franceses, italianos, norte-americanos, alemães, ingleses - contratados em seus países para lecionarem nas novas faculdades.

No que se refere à história, inclusive à história do Brasil, em seus diferentes setores, foi certamente decisiva e continua a sê-lo, sobre as novas gerações, a ação de alguns daqueles mestres: de um Jean Gagé, por exemplo, e de um Fernand Braudel em São Paulo; de um Henri Hauser e de um Eugène Albertini, na hoje extinta Universidade do Distrito Federal. O que puderam realizar até aqui, no sentido de sugerir novos tipos de pesquisa e suscitar problemas novos, é apenas sensível, por ora, em certos tipos de trabalho - cursos especiais, seminários, teses de concurso -, que pela sua mesma natureza hão de fugir ao alcance de um público numeroso. Não parece excessivo acreditar, entretanto, que neles já se encontra o gérmen de um desenvolvimento novo e promissor dos estudos históricos no Brasil.

Sérgio Buarque de Holanda (1951) 